University of Chicago Law School

Chicago Unbound

Journal Articles

Faculty Scholarship

1981

\title{
The Proper Role of a Target's Management in Responding to a Tender Offer
}

Frank H. Easterbrook

Daniel R. Fischel

Follow this and additional works at: https://chicagounbound.uchicago.edu/journal_articles

Part of the Law Commons

\section{Recommended Citation}

Frank H. Easterbrook \& Daniel R. Fischel, "The Proper Role of a Target's Management in Responding to a Tender Offer," 94 Harvard Law Review 1161 (1981).

This Article is brought to you for free and open access by the Faculty Scholarship at Chicago Unbound. It has been accepted for inclusion in Journal Articles by an authorized administrator of Chicago Unbound. For more information, please contact unbound@law.uchicago.edu. 


\section{HARVARD LAW REVIEW}

\section{THE PROPER ROLE OF A TARGET'S MANAGEMENT IN RESPONDING TO A TENDER OFFER}

\section{Frank H. Easterbrook* and Daniel R. Fischel**}

Under existing federal and state law, a corporation's managers can resist and often defeat a premium tender offer without liability to either the corporation's shareholders or the unsuccessful tender offeror. Professors Easterbrook and Fischel argue that resistance by a corporation's managers to premium tender offers, even if it triggers a bidding contest, ultimately decreases shareholder welfare. Shareholders would be better off, the authors claim, were such resistance all but proscribed. The authors consider, but find wanting, a number of potential criticisms of their analysis; they conchude by proposing a rule of mangerial passivity capable of controlling resistance in actual cases.

A

cash tender offer typically presents shareholders of the "target" corporation with the opportunity to sell many if not all of their shares quickly and at a premium over the market price. ${ }^{1}$ Notwithstanding the apparent benefit both to shareholders of the target and to the acquirer when such offers succeed, the target's management may oppose the offer, arguing that the premium is insufficient or that the corporation would be harmed by its new owners. To defeat the offer, management may file suits against the offeror, sell new shares to dilute the offeror's holdings, manufacture an antitrust prob-

* Assistant Professor of Law, University of Chicago.

** Assistant Professor of Law, Northwestern University. The Authors thank Walter J. Blum, Michael Bradley, Lea Brilmayer, Dennis W. Carlton, Peter Dodd, Richard A. Epstein, Mayer Freed, Leo Herzel, Gregg A. Jarrell, Edmund W. Kitch, Douglas M. Kraus, John H. Langbein, Douglas Laycock, Bernard D. Meltzer, Daniel Polsby, Richard A. Posner, Stephen Presser, David S. Ruder, Myron Scholes, Kenneth E. Scott, Stephen M. Shapiro, Matthew L. Spitzer, Robert S. Stillman, Harry Watson, and participants at the law and economics workshops of Harvard and the University of Chicago Law Schools for their helpful comments. The Law and Economics Program of the University of Chicago provided support for the writing of this Article; David Glazer furnished assistance in the research.

'See, e.g., Panter v. Marshall Field \& Co., 486 F. Supp. Ir68 (N.D. Ill. I980), appeal docketed, No. 80-1375 (7th Cir. Mar. 21, 1980). Marshall Field involved a shareholder's suit against management for defeating a tender offer with a premium exceeding $100 \%$ of the price just prior to formulation of offer plans. 
lem by acquiring one of the offeror's competitors, or engage in a wide variety of other defensive tactics. ${ }^{2}$ Sometimes the resistance leads to the target's being acquired at a price above the initial bid, either by the original bidder or by a "white knight," 3 and sometimes the resistance defeats the takeover attempt altogether. ${ }^{4}$

The ability of management to engage in defensive tactics in response to a cash tender offer is a relatively recent development in contests for corporate control. Prior to the enactment of the Williams $\mathrm{Act}^{5}$ in $\mathrm{I} 968$, offerors were free to structure offers in a manner designed to force shareholders to decide quickly whether to sell all or part of their shares at a premium. ${ }^{6}$ The target's management consequently had little time to mobilize a defensive strategy to impede the offer. The Williams Act, however, has deprived the offeror of this advantage of speed by regulating the conditions under which the offer can be made. ${ }^{7}$ More than half the states have enacted

2 The common defensive stratagems are set out in E. ARANow, H. EINHORN \& G. Berlstein, Developments in Tender Offers for Corporate Control 193-206 (1977); A. Fleischer, Tender OfFers: Defenses, Responses and PlanNing (1978); M. LIPTON \& E. STEINBERger, Takeovers aNd FreEzeouts \$§ 6.46.6.3 (1978 \& Supp. I980); Hochman \& Folger, Deflecting Takeovers: Charter and By-Law Techniques, 34 Bus. LAw. 537 (I979); Nathan \& Sobel, Corporate Stock Repurchases in the Context of Unsolicited Takeover Bids, 35 Bus. LAw. I545 (1980).

${ }^{3}$ The recent battle between J. Ray McDermott, Inc., and Wheelabrator-Frye, Inc., for control of Pullman, Inc., provides a notable illustration of the "white knight" phenomenon. McDermott initiated the bidding at $\$ 28$ per share in July 1980. Wheelabrator-Frye won the fight several months later with a bid of \$52.50 per share, covering more than five times the number of shares $\mathrm{McDermott}$ offered to purchase initially. See McDermott, Inc. v. Wheelabrator-Frye, Inc., No. 80-2306 (7th Cir. Sept. 25, I980); Wall St. J., Aug. 22, I980, at 2, col. 2; id., Sept. I7, I980, at 4, col. 2; id. , Sept. I8, 1980, at 55, col. I.

${ }^{4}$ See, e.g., Lewis v. McGraw, 619 F.2d 192 (2d Cir.), cert. denied, ror S. Ct. 354 (I980); Panter v. Marshall Field \& Co., 486 F. Supp. Ir68 (N.D. Ill. I980), appeal docketed, No. 80-1375 (7th Cir. Mar. 21, 1980); Labaton Co. v. Universal Leaf Tobacco Co., [1979 Transfer Binder] FED. SEC. L. REP. (CCH) ף 96,943 (S.D.N.Y. I979); Berman v. Gerber Prods. Co., 454 F. Supp. 1310 (W.D. Mich. 1978); Grossman, Faber \& Miller, P.A. v. Cable Funding Corp., [1974-1975 Transfer Binder] FEd. SEC. L. REP. (CCH) If 94,913 (D. Del. 1974); Northwest Indus. v. B.F. Goodrich Co., 30I F. Supp. 706 (N.D. Ill. I969).

5 I5 U.S.C. $\$ \$ 78 \mathrm{~g}, 78 \mathrm{l}-78 \mathrm{n}, 78 \mathrm{~s}$ (1976).

${ }^{6}$ Before I 968 offerors could limit the time an offer would be available, require that tenders be irrevocable, or specify that if the offer should be oversubscribed the first shares to be tendered would be the first to be purchased. Offers with such terms produced considerable pressure for shareholders to tender quickly, lest they lose the opportunity to realize the favorable terms.

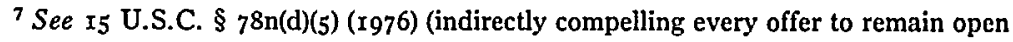
for at least seven days by allowing shareholders to withdraw any shares they have tendered during that time); I7 C.F.R. 240.14d-7(a)(I) (r980) (rule promulgated by the Securities and Exchange Commission extending the minimum period to 15 business 
tender offer statutes that go beyond the Williams Act in placing restrictions on the ability of an offeror to wage a tender offer. ${ }^{8}$ The effect of state and federal regulation of tender offers has been to give the target's management the time to undertake a defensive strategy. ${ }^{9}$

The reaction of shareholders to managerial resistance depends on the outcome. Few protest when resistance leads to a takeover at a higher price. When resistance thwarts the takeover attempt altogether, however, litigation usually follows. Although defeat of the takeover attempt may deprive the target's shareholders of a substantial premium, shareholders' suits against management to recover this loss are almost always unsuccessful. ${ }^{10}$ Relying on the business judgment rule, .courts typically have held that the target's management has the right, and even the duty, to oppose a tender offer it . determines to be contrary to the firm's best interests. ${ }^{11}$ Commentators generally have applauded the results of these cases. ${ }^{12}$

days); I7 C.F.R. 240. I4d-7(a)(2) (I980) (SEC rule requiring the offer to remain open for Io business days after another bidder makes a tender offer for the same class of securities). For a criticism of the Williams Act, see Fischel, Efficient Capital Market Theory, the Market for Corporate Control, and the Regulation of Cash Tender Offers, 57 TEx. L. REv. I (1978).

$\mathbf{8}$ To the extent that the state statutes are less hospitable to hostile takeover bids than the Williams Act, they are of doubtful constitutionality. Compare Kennecott Corp. v. Smith, 637 F.2d 18I (3d Cir. r980), and MnTE Corp. v. Dixon, 633 F.2d 486 (7th Cir. I980), appeal docketed sub nom. Edgar v. MITE Corp., 49 U.S.L.W. 3533 (U.S. Jan. 15, 1981) (No. 80-1r88), and Great W. United Corp. v. Kidwell, 577 F.2d 1256 (5th Cir. I978), rev'd on other grounds sub nom. Leroy v. Great W. United Corp., 443 U.S. 173 (1979), and Dart Indus. v. Conrad, 462 F. Supp. I (S.D. Ind. 1978) (unconstitutional), with Telvest, Inc. v. Bradshaw, 618 F.2d 1029 (4th Cir. I980) (probably constitutional), and AMCA Int'l Corp. v. Krouse, 482 F. Supp. 929 (S.D. Ohio 1979) (constitutional), and Unitrode Corp. v. Dynamics Corp. of Am., 399 N.E.2d 5 (Mass. I980) (construing state statute to avoid constitutional problems). See generally Note, Securities Lave and the Constitution: State Tender Offer Statutes Reconsidered, 88 YALE L.J. 5 ro (r979).

9 This has been recognized in several recent decisions that have held state tender offer statutes to be unconstitutional. See Kennecott Corp. v. Smith, 637 F.2d I8I (3d Cir. I980); MITE Corp. v. Dixon, 633 F.2d 486 (7th Cir. 1980), appeal docketed sub nom. Edgar v. MITE Corp., 49 U.S.L.W. 3533 (U.S. Jan. 15, 1981) (No. 80Ir88).

${ }^{10}$ See, e.g., Lewis v. McGraw, 6rg F.2d 192 (2d Cir.), cert. denied, ror S. Ct. 354 (I980); Panter v. Marshall Field \& Co., 486 F. Supp. II68 (N.D. Ill. 1980), appeal docketed, No. 80-1375 (7th Cir. Mar. 2I, I980); Berman v. Gerber Prods. Co., 454 F. Supp. I310 (W.D. Mich. I978). See also Treadway Cos. v. Care Corp., 638 F.2d 357 (2d Cir. 1980), rev'g in part 490 F. Supp. 668 (S.D.N.Y. I980), discussed at note Ior infra.

${ }^{11}$ E.g., Panter v. Marshall Field \& Co., 486 F. Supp. II68 (N.D. Ill. I980), appeal docketed, No. 80-1375 (7th Cir. Mar. 21, 1980).

${ }^{12}$ See, e.g., Herzel, Schmidt \& Davis, Why Corporate Directors Have a Right to 
We argue in this Article that current legal rules allowing the target's management to engage in defensive tactics in response to a tender offer decrease shareholders' welfare. The detriment to shareholders is fairly clear where defensive tactics result in a defeat of a takeover, causing shareholders to lose the tender premium. Even where resistance leads to a higher price paid for the firm's shares, however, shareholders as a whole do not necessarily benefit. The value of any stock can be understood as the sum of two components: the price that will prevail in the market if there is no successful offer (multiplied by the likelihood that there will be none) and the price that will be paid in a future tender offer (multiplied by the likelihood that some offer will succeed). A shareholder's welfare is maximized by a legal rule that enables the sum of these two components to reach its highest value. Any approach that looks only at the way in which managers can augment the tender offeror's bid, given that a tender offer has already been made, but disregards the effect of a defensive strategy on the number of offers that will be made in the future and the way in which the number of offers affects the efficiency with which corporations are managed, ignores much that is relevant to shareholders' welfare.

We attempt in Part I to furnish what the existing legal literature and case law lacks: a framework for understanding how defensive tactics affect the number of tender offers, the price if an offer is made, and the price of stock in the event no offer is made. Our investigation leads to the conclusion that shareholders' welfare is maximized by an externally imposed legal rule severely limiting the ability of managers to resist a tender offer even if the purpose of resistance is to trigger a bidding contest. In Part II we consider and reject a number of the arguments which have been raised against our analysis of the proper role of a target's management in response to a tender offer. Finally, in Part III we propose a rule of managerial passivity that could be applied to control resistance to tender offers, and show that such a rule would not be inconsistent with the prevailing principles of fiduciary duty that apply to managers or with the business judgment rule.

Resist Tender Offers, 3 CORP. L. Rev. IO7 (1980); Lipton, Takeover Bids in the Target's Boardroom, 35 Bus. LAW. IOI (1979); Steinbrink, Management's Response to the Takeover Attempt, 28 CASE W. L. REV. 882 (1978). See also A. FleISChER, supra note 2; Hochman \& Folger, supra note 2; M. LIPTON \& E. STEINBERGER, supra note 2. Other authors, although skeptical about the motivation for resistance, would allow defensive tactics in certain circumstances. See, e.g., Gelfond \& Sebastian, Reevahating the Duties of Target Management in a Hostile Tender Offer, 60 B.U.L. REv. 403 (r980); Lynch \& Steinberg, The Legitimacy of Defensive Tactics in Tender Offers, 64 CORNELL L. REV. gOI (I979). 


\section{Defenstve Tactics and Shareholder WeLFare}

A cash tender offer at a premium over the market price gives each shareholder the opportunity to obtain, with certainty, a return exceeding the current market value of the target's stock. It would be possible, if overly simple, to stop at this point and conclude that tender offers are beneficial to the target's shareholders. Simple ideas do not always survive scrutiny, and this one has been subject to challenge on the ground that the market price of shares does not reflect their real worth. Instead, it is argued, the price of shares must be too low at the time of the offer, for how else could the prospective acquirer offer to pay a premium? We address these concerns in Section A below. In subsection I we examine how the price of shares comes to reflect their value. In subsection 2 we discuss why bidders might offer more than the market price. We then use the principles explained in Section $A$ to show in Section B how shareholders would be best off if managers did not resist tender offers.

\section{A. Tender Offers and the Markets for Stock and Managers}

I. Efficient Capital Market Theory and the Price of Tender Offers. - It is very unlikely that price and "value" will diverge in large markets for shares. If there were such divergences, investors could reap substantial gains by identifying and buying underpriced shares and selling overpriced shares. ${ }^{13}$ Since there are many sophisticated investors with ample capital, the arbitrage process would proceed quite quickly, and it would become impossible to make systematic gains by finding undervalued shares. As investors bought and sold on the basis of what they knew, their very activity would drive the price toward the correct one. The change in the price would reduce the gains available from identifying mispriced shares. Indeed, once information about a firm reached the market, prices would adjust quickly whether or not anyone traded, because no trader with rational expectations would sell for less than the price he expected the shares to reach once the news became widespread.

The process of estimation and trading leads to prices that embody all of the available information about the value of the shares. Commonly referred to as the "efficient capital market hypothesis," the proposition that it is not possible to make abnormal gains by identifying and trading in mispriced stocks

${ }^{13}$ A share is "underpriced" or "overpriced" in relation to some future price. We do not imply that a share has any intrinsic value. 
has been widely accepted. ${ }^{14}$ It means that the price of shares reflects the collective wisdom of all traders about the value of the stock, and it also means that there is no reliable way to determine the direction, amount, or even existence of any difference between today's and tomorrow's price. If capital markets are efficient, as the evidence shows them to be, ${ }^{15}$ then any statement that a given stock is really worth more than its

${ }^{14}$ See note 15 infra. The statement that investors do not usually profit by acquiring new information in an efficient capital market raises interesting problems. If the price of shares fully incorporates information about the firm, then no one has an incentive to gather additional information. Yet information-gathering, followed by trading, is the process by which prices come to embody the information. The more closely price follows information, it seems, the less information there will be, and consequently the more profitable it becomes to gather new information and beat the market. The matter is not, however, paradoxical. Market participants will simply secure information to the point where the marginal dollar invested in research equals the gain to be had from making better projections. There will not be an equilibrium with perfect information, but there is an "equilibrium degree of disequilibrium." Grossman \& Stiglitz, On the Impossibility of Informationally Efficient Markets, 70 Am. Econ. Rev. 393 (1980). See also Langbein \& Posner, Market Funds and TrustInvestment Law: II, 1977 AM. B. Foundation Research J. 1, 7-12. Because information spreads quickly through the market, this equilibrium will be an optimal guess about tomorrow's price of shares. Even though some people can make a living by acquiring and trading on information, it is unlikely that anyone could improve on the informativeness of the share's price as a method of summarizing the available supply of knowledge.

is Several kinds of evidence support the proposition that stock markets are efficient: (I) Stock prices cannot be predicted by any mechanical rule, and the trend of past prices provides no guidance about the trend of future prices. This indicates that the current price already embodies any information obtainable from trends. (2) Stock prices adjust rapidly to newly disclosed information, and the price adjustments are unbiased in the sense that they do not systematically overshoot or undershoot the eventual price. In most cases, the price adjustments actually precede the release of new information, and there is thus no change at all when an apparently significant disclosure is made. This indicates that "information leakage," see Hirshleifer \& Riley, The Analytics of Uncertainty and Information - An Expository Survey, I7 J. ECoN. LITERATURE I375, I403-II (1979), and the concomitant trading that occurs in anticipation of announcements make the announcements themselves superfluous. In short, stock prices embody all of the "public" information and more. (3) Changes in firms' accounting practices, and hence in their apparent profits, have no effect on price. This indicates that markets discount firms' attempts to manipulate information pertinent to price. Similarly, other changes of form, such as stock splits, also have no effect on price, if adjusted for changes in dividend rate. (4) Market professionals are unable to do better than casual investors in predicting stock movements. Professionally managed mutual funds, for example, do not perform better than portfolios selected at random. (5) The elaborate disclosures required by the SEC do not make investors better off; returns are no higher now than they were in the I920's. See generally J. Lorie \& M. Hamilton, The Stock Market: Theories and Evidence 70-98 (1973); Fama, Efficient Capital Markets: A Review of Theory and Empirical Work, 25 J. FinANCE 383 (1970); Jensen, Capital Markets: Theory and Evidence, 3 BELL J. Econ. \& Management ScI. 357 (1972); Note, The Efficient Capital Market Hypothesis, Economic Theory and the Regulation of the Securities Industry, 29 STAN. L. REV. 1031, 1034-57 (1977). 
price is not believable; ${ }^{16}$ if a guess better than the market's guess could be devised, the cost of making the improvement (including the payments to researchers and analysts) would exceed the gains from the knowledge.

It may be helpful to think of stock prices as reflecting estimates of the probabilities of future states of the world. To a great extent, price movements depend on the state of the economy, the rate of interest, demand for the firm's product, the skill (or luck) of the firm's managers, and so on. The price of the stock on any given day will be a composite of the prices the stock would assume under different assumptions about the future. Suppose that the fortunes of one firm depend on the success of some innovative process. If the process works, the future earnings of that firm will be worth $\$ 100$ per share; if it flops, the earnings will be worth only $\$ 20$. If failure is 3 times as likely as success, then the shares will trade for $\$ 40 .^{17}$ The price of the shares will rise or fall as new information sheds light on either the probability of success (an increase to I chance in 2 will lead to a price of $\$ 60$ ) or the profits if the venture succeeds. Changes in the interest rate would affect the way in which these earnings streams are discounted to present value, thus affecting the price of shares. Other influences work in a similar way.

This illustrates why the constant, sometimes violent, movement of share prices is consistent with the proposition that markets are efficient. When price changes, the change does not show that the old price was wrong; it shows only that new information has been incorporated into the price of the stock.

We can conclude from this, with some confidence, that a tender offer at a price higher than the prevailing one also

${ }^{16}$ For an argument that a market averages people's weighted beliefs about the future and that the resulting prices are a better estimate of the correct probabilities than any of the participants' estimates, see Verrecchia, Consensus Beliefs, Information Acquisition, and Market Information Efficiency, 70 AM. ECON. REV. 874 (1980).

17 The $\$ 40$ figure is simply the average of the two outcomes weighted by their relative probabilities of occurrence: $(75 \% \times 20)+(25 \% \times 100)=40$. We assume here that investors are risk neutral (indifferent to risk). A person is risk neutral if he would pay the same amount for a ticket that entitled him to $\$ I$ as he would for a ticket that entitled him to participate in a coin flip in which he would receive $\$ 2$ for calling the coin correctly. If he would pay more for the $\$ 2$ ticket, he is risk preferring; if he would pay less for the $\$ 2$ ticket, he is risk averse. In the example, the shares will trade for less than $\$ 40$ if the shareholders are risk averse, more than $\$ 40$ if they are risk preferring. Whether shareholders act if risk averse depends on the extent to which the risks of a particular stock can be eliminated by diversifying (i.e., owning a basket of many stocks). Both theory and evidence suggest that if the risks are diversifiable, shareholders will be indifferent to them; otherwise they will be risk averse. See J. LORIE \& M. Hamilton, supra note 15 , at I7 I-259. 
exceeds the value of the stock. True, the target's managers may know something about the firm's prospects not yet incorporated into the price of the shares. ${ }^{18}$ But the disparity between price and worth could not last long. If a bidder tried to steal the target by capitalizing on its special information, the target's managers could defeat the offer by disclosing the information to the public. ${ }^{19}$ The price would adjust to reflect the new information, and the offer would succeed only if it were higher than the new price. Tender offers at a premium thus must benefit the target's shareholders.

2. Agency Costs and Takeovers. - Although the efficiency of capital markets implies that shareholders gain from tender offers, it also seems to imply that bidders are irrational. Why can a bidder identify underpriced stocks if market professionals cannot? The bidder's knowledge would be shared by the target's management in most cases, and management could release the information, causing a price adjustment. The simple fact that the bidder has made an offer might cause the information to leak to the market. Unless stock markets are sub. stantially inefficient, ${ }^{20}$ the bidder will not be able to acquire a company for less than its.value under current conditions.

Commentators have proposed a bewildering number of explanations for mergers and takeovers. They include gains from

18 If there were no prohibitions against insider trading, shares would not sell for less than a price incorporating all information, since insider trades would move prices to reflect even corporate secrets. See Fischel, supra note 7, at 24.

19 If the firm needed to act in secret to realize the value of its knowledge, management would be dutybound not to reveal the information. See, e.g., SEC v. Texas Gulf Sulphur Co., 401 F.2d 833, 843-44, 850 n. I2 (2d Cir. r968) (en banc) (secrecy needed to enable acquisition of land under which the corporation had discovered valuable ore of which the landowner was not aware), cert. denied, 404 U.S. 1005 (1971). The existence of a duty to maintain secrecy, even in the face of a tender offer for less than the eventual price of the stock, may constitute an exception to our more general conclusion that shareholders' welfare would be maximized by managerial passivity in response to tender offers. It is not an exception, however, if there is a competitive market in acquisitions or if shareholders have rational expectations about the prospects of their firms. Competitive bidders would protect the shareholders' interests fully. For the technical argument about rational expectations, see S. Grossman \& O. Hart, The Allocational Role of Takeover Bids in Situations of Asymmetric Expectations (U. Pa. Wharton School, White Center for Financial Research, Working Paper No. 6-80, Jan. r980). For an empirical argument that shareholders do have rational expectations, see Bradley, Interfirm Tender Offers and the Market for Corporate Control, $53 \mathrm{~J}$. Bus. 345 ( 1980 ).

${ }^{20}$ The qualification is important. Stocks traded over the counter may not always have sufficiently liquid markets (or may not be the subject of sufficiently frequent scrutiny) to ensure that their prices reflect all available information. If markets for particular stocks are not efficient, it is not possible to say that every tender bid at a premium is beneficial to shareholders. Even so, however, all of the arguments about agency costs apply to these firms, and they support a rule of managerial passivity. 
increasing the ability of firms to employ information that would leak if conveyed between independent entities, "synergy" gains as the combined firms obtain the value of some savings in joint operations, and tax benefits. None of these explanations is implausible, and none is inconsistent with a belief that tender offers improve shareholders' welfare. ${ }^{21}$ But the savings and benefits attributable to each could be achieved by friendly merger as well as by hostile tender offer. Since a tender offer is by far the more costly device, ${ }^{22}$ one must consider whether some source of benefit both accounts for large cash premiums and explains why a friendly merger did not occur.

The most probable explanation for unfriendly takeovers emphasizes their role in monitoring the performance of corporate managers. The tender bidding process polices managers whether or not a tender offer occurs, and disciplines or replaces them if they stray too far from the service of the shareholders. ${ }^{23}$ We offer the following explanation both to show what we mean by agency $\operatorname{costs}^{24}$ and to illustrate how the tender bidding process influences these costs.

Corporate managers (which include both officers and members of the board), like all other people, work harder if they

21 The suggestion that offerors are attempting to realize the gains from nonpatentable information appears in Jarrell \& Bradley, The Economic Effects of Federal and State Regulations of Cash Tender Offers, 23 J.L. \& EcoN. 37 I (1980). They view this as a welfare-increasing process. "Synergy," if it exists, also obviously increases welfare. Tax reasons may seem more problematic. The acquired firm may have a valuable tax loss or cash that can be passed to shareholders at the capital gains rate through an acquisition. Moreover, a tender offer may capitalize the target's earnings stream, distributing it as capital gains. Even tax-motivated takeovers improve effciency: they free up assets that the target may be holding as cash (or investing suboptimally) to avoid a distribution at high tax rates. The tender offeror receives and can invest these assets without recognizing taxable gain. And, of course, a firm may have acquired a tax loss as a result of suboptimal management. Finally, even though a firm with inferior managers could achieve tax savings through an acquisition, it is the firm with the best combination of tax advantages and good management that can make the highest bid for the target. Given competition among acquirers, any tax-motivated takeover is unlikely to reduce the efficiency with which the target's assets are used.

${ }^{22}$ The average cost of a tender offer before 1975 was $13 \%$ of the total postoffer market price of the shares. Smiley, Tender Offers, Transactions Costs and the Theory of the Firm, 58 REv. ECON. \& STATISTICS 22, 30 (I976).

${ }^{23}$ See Manne, Mergers and the Market for Corporate Control, 73 J. PoL. ECoN. I Io (1965).

24 This use of "agency costs" was introduced by Jensen \& Meckling, Theory of the Firm: Managerial Behavior, Agency Costs and Ownership Structure, 3 J. Financial ECON. 305 (1976). See also Alchian \& Demsetz, Production, Information Costs, and Economic Organization, 62 AM. ECON. REv. 777 (r972). 
can enjoy all of the benefits of their efforts. In a corporation, however, much of the benefit of each manager's performance inures to someone else, whether it be shareholders, bondholders, or other managers. The investors must be given a substantial share of the gains to induce them to put up their money. ${ }^{25}$ Because no single manager receives the full benefit of his work, he may find that, at the margin, developing new ventures and supervising old ones takes too much effort to be worthwhile; each manager may reason that someone else is apt to do the work if he does not or to take the rewards even if he does well. No manager will be completely vigilant. So some managers will find it advantageous to shirk responsibilities, consume perquisites, or otherwise take more than the corporation promised to give them. One especially important way in which managers' performance falls short of the ideal is in choosing the firm's other agents. Because no manager can obtain all of the benefits available to the firm from making good decisions, none takes all cost-justified steps to recruit and train those employees best suited for their jobs. As a result, many firms will have some employees less than completely dedicated to their jobs and other employees who, although fully dedicated, ought not to be in the positions they hold. These agency costs of less than optimal management cause the firm's shares to trade for less than the price they would achieve if agency costs were zero.

Shareholders might be able to reap substantial gains from improving the performance of managers as their agents. ${ }^{26}$ But this improvement is difficult to achieve, and the difficulty is

${ }^{25}$ Any siphoning of benefits by the managers is an agency cost even if the managers put the existing resources of the firm to their socially optimal use. Unless all of the benefits of new investment are returned to those who supply the firm's capital, there will be too little investment in the future. The reduction in the incentive to invest is a real social cost.

${ }^{26}$ This is not to suggest that there is something undesirable in the fact that many firms are controlled by managers rather than by stockholders. This "separation of ownership and control," criticized so harshly in A. BERLE \& G. MEANS, THE MODERN Corporation and Private Property (1932), and, less thoughtfully, in R. Nader, M. Green \& J. Seligman, Taming the Giant Corporation (1976), is nothing but another way of describing the division of labor. The separation enables skilled managers to run enterprises even though they lack personal wealth, and it enables those who have wealth to invest even though they lack managerial skills. Moreover, this division of labor also enables investors to diversify their portfolios, in turn lowering risk and making investment more attractive. See Langbein \& Posner, Market Funds and Trust-Investment Law, I976 AM. B. Foundation RESEARCH J. I; Posner, The Rights of Creditors of Affiliated Corporations, 43 U. CHI. L. REV. 499 (1976).

Corporations are contractual undertakings, and the founders of a corporation can select that set of arrangements which maximizes their welfare. Separation of ownership and control would not emerge or survive if it did not serve important functions. See R. WINTER, GOVERNMENT AND THE CORPORATION (1978). If separation were not highly functional, investors would not entrust their money to managers. (Surely 
the reason why outsiders (tender bidders) play an important role. The agency costs typically will go undetected by individual shareholders. Most shareholders are passive investors seeking liquid holdings. They have little interest in managing the firm and less incentive to learn the details of management. No one shareholder can collect all or even a little of the gains available from monitoring the firm's managers. The benefits would be dispersed among all stockholders according to their investments, not according to their monitoring efforts. Because other shareholders take a free ride on any one shareholder's monitoring, each shareholder finds it in his self-interest to be passive. He simply sells his shares if he is dissatisfied.

The free riding problems that inhibit monitoring by shareholders are aggravated by the difficulty any shareholder would face in doing anything about the firm's managers once he discovered the existence of excessive agency costs. The shareholder who makes the discovery has no authority to compel the firm to change its ways. He must either persuade the managers or induce his fellow shareholders to oust the managers and install new ones. Yet persuasion is lost on misbehaving managers who need not listen. The cry of "turn the rascals out" also is not of much use, because other shareholders still find it in their self-interest to be passive. The shareholder who has made the discovery must persuade his fellow shareholders to invest a significant amount of time in studying the corporation's affairs. These shareholders would be willing to do so only if their attention and study could yield a benefit. But here, too, free riding makes things difficult. Each shareholder will recognize that his votes will not affect the outcome of any dispute unless he has a large bloc of shares. As a result, each shareholder's self-interest leads him to ignore the controversy; it is costly to become informed, and the cost produces little prospect of benefit. If each shareholder reasons in the same way, as he should, the managers of the firm will prevail in any contest about their operation of the company. And that is the pattern in the market. Shareholders routinely vote for managers or pay no attention to elections. Successful campaigns against managers are rare, and they seldom succeed even if one dissident shareholder holds a large bloc of stock that he can vote in his own favor. ${ }^{27}$

managers of large corporations have no monopsony power over investment opportunities.) The point we make in the text is consistent with a belief that, if shareholders were required to "control" corporations more tightly than they do now, the price of shares would be still lower.

27 The proclivity of money managers and trustees to vote for corporate management - much maligned in the legal literature - doubtless accounts for some of management's lopsided success. But, for the reasons we have given in text, share- 
Corporate managers recognize that they can improve the performance of the firm by reducing agency costs. Managers monitor each other's performance and reward achievements; bonuses and salary adjustments could be a form of "ex post settling up" that substantially alleviates incentive problems, as Eugene Fama has argued. ${ }^{28}$ Gary Becker and George Stigler have supplied a strong argument that if managers enjoy especially favorable salaries or other terms of employment, they may be disciplined by the prospect of being fired. ${ }^{29}$ Pensions and retirement bonuses also help to coax good performance from managers. ${ }^{30}$

These devices, although more useful than monitoring by shareholders, still are imperfect. They depend on the ability of the firm to discriminate good performance from inferior performance by each employee. But because managers typically work in teams, it is hard to determine the contribution of each person. ${ }^{31}$ The output of one group of managers depends on the quality of information and options supplied by another group, and so on. The attempt to determine the marginal contribution of each manager is bound to be difficult and costly. Worse, the attempt to meter the contributions of each manager, and to dispense rewards accordingly, encounters the free rider problem we have discussed. Because no manager can obtain all of the benefits of monitoring his col-

holders would not be better off under a regime requiring trustees to make a "reasoned judgment" on contested matters or to pass voting rights through to the beneficial owners. If, as we have argued, the shareholders' self-interest has led them to be ignorant and passive, a rule compelling them or their nominees to become informed cannot make them better off. See Langbein \& Posner, supra note I4.

${ }^{28}$ See Fama, Agency Problems and the Theory of the Firm, 88 J. PoL. Econ. 288, 295-306 (1980). Fama neglects, however, the problem of the discount rate. If inferior management is not discovered for some time after the event, it may be impossible to achieve a satisfactory ex post settling up.

${ }^{29}$ See Becker \& Stigler, Law Enforcement, Malfeasance, and Compensation of Enforcers, 3 J. LEGAL STUD. I, 9-10 (1974).

${ }^{30}$ The incentive provided by such devices obviously increases as the manager nears retirement. So, too, does the need to give the manager an incentive. As a manager becomes older, the effect on his future earnings of today's shirking and malfeasance becomes smaller, and in the period just before retirement the manager's incentive to work hard is smallest of all. See Becker \& Stigler, supra note 29; Klein, Crawford \& Alchian, Vertical Integration, Appropriable Rents, and the Competitive Contracting Process, 21 J.L. \& EcoN. 297, 304 \& n.I7 (1978). Although ERISA bars the forfeiture of pensions for misconduct and shirking, it does not prevent firms from withholding retirement bonuses from its employees. See Hepple v. Roberts \& Dybdahl, Inc., 622 F.2d 962 (8th Cir. I980).

31 This explains why stock options and other profit sharing plans, which attempt to minimize agency costs by making managers "owners," cannot be very effective. In a large corporation, any one manager's efforts are likely to have only a trivial effect on the price of the firm's shares. 
leagues, each one will be less than fully dedicated to the task. ${ }^{32}$ Even the most dedicated manager will find it difficult to fire or discipline an old friend when the benefits of ruthlessness accrue to distant and unknown shareholders.

The methods of metering and monitoring within a firm are thus unlikely to work well unless the management team as a whole is subject to supervision and, if necessary, discharge. The prospect that the team's work will be judged as a whole gives senior managers a powerful incentive to create and use intra-management control devices. Yet, as we have explained, shareholder monitoring cannot supply the necessary supervision.

Tender offers are a method of monitoring the work of management teams. Prospective bidders monitor the performance of managerial teams by comparing a corporation's potential value with its value (as reflected by share prices) under current management. When the difference between the market price of a firm's shares and the price those shares might have under different circumstances becomes too great, an outsider can profit by buying the firm and improving its management. The outsider reduces the free riding problem because it owns a majority of the shares. The source of the premium is the reduction in agency costs, which makes the firm's assets worth more in the hands of the acquirer than they were worth in the hands of the firm's managers.

All parties benefit in this process. The target's shareholders gain because they receive a premium over the market price. ${ }^{33}$

32 Alchian \& Demsetz, supra note 24, suggests that there would always be inefficient management unless the ultimate supervisor received all of the firm's profits. As we have explained in the text, in a publicly held corporation the shareholders (who have the residual entitlement to profits) lack the incentive to serve as monitors.

${ }^{33}$ But see Grossman \& Hart, Takeover Bids, the Free-Rider Problem, and the Theory of the Corporation, II BELL J. ECON. 42 ( 1980 ). While recognizing the power of the tender offer in disciplining management, Grossman and Hart believe that an offeror could not induce the shareholders to part with their shares unless it had some way of appropriating to itself the gains from the acquisition. They observe that, if the offeror plans to profit by improving the firm's management, then it must expect the postacquisition price of shares to be even higher than the offer price. Consequently, they reason, a shareholder will prefer the postoffer price to the tender price, and he will not tender if his holdings are so small that they cannot affect the success of the offer. And, of course, if everyone reasons in the same way, the offer will fail. Grossman and Hart conclude that offerors should be able to "dilute" the price of shares after the acquisition in order to overcome this tendency not to tender. Shareholders, knowing that dilution could follow the acquisition, will tender their shares, and thus the threat of dilution need never be carried out.

This argument is not compelling. The tender offeror has two potent devices that overcome the holdout problem. First, the offeror may specify that the offer is contingent on receipt of a sufficiently large percentage of the shares so that any share- 
The bidder obtains the difference between the new value of the firm and the payment to the old shareholders. Nontendering shareholders receive part of the appreciation in the price of the shares. ${ }^{34}$

More significantly for our purposes, shareholders benefit even if their corporation never is the subject of a tender offer. The process of monitoring by outsiders poses a continuous threat of takeover if performance lags. Managers will attempt to reduce agency costs in order to reduce the chance of takeover, and the process of reducing agency costs leads to higher prices for shares. ${ }^{35}$ We now explore how different responses to takeover bids influence the size of the benefit derived from monitoring by outsiders in advance of any offer.

\section{$B$. The Consequences of Management's Defensive Tactics}

I. Resistance and Agency Costs. - The argument presented above establishes that takeovers are beneficial to both shareholders and society. It follows that any strategy designed to prevent tender offers reduces welfare. If the company adopts a policy of intransigent resistance and succeeds in maintaining its independence, the shareholders lose whatever pre-

holder's decision could affect the success of the offer. Since each shareholder knows that all other shareholders will reason the same way he does, he will tender in order to obtain the premium. Second, the offeror can acquire all of the shares with a freezeout merger after it obtains control. See DEL. CODE ANN. tit. 8, § 262(f) (1974); Model Bus. CoRP. ACT $\S 8 \mathrm{I}(\mathrm{a})(3)$ (1978). But cf. Singer v. Magnavox Co., 380 A.2d 969 (Del. 1977) (requiring merger price to be fair). See Brudney \& Chirelstein, $A$ Restatement of Corporate Freezeouts, 87 YALE L.J. 1354, I359-65 (1978) (criticizing restrictions on two-step freezeouts). Once the shareholders understand that holding out will not enable them to obtain more than the tender offer price, they have an incentive to tender their shares to obtain the premium as soon as possible.

The idea of dilution is nonetheless important in establishing rules with respect to management's response to a tender offer. The ability of the offeror to obtain the shares for less than their value in the hands of new management can be thought of as dilution, and the existence of this dilution is essential to the profitability (and hence the existence) of tender offers. See p. 1177 infra. The available evidence suggests that share prices are "diluted" in this way. See Bradley, supra note 19.

34 The price of shares typically increases substantially after a tender offer, see note 76 infra, and state law often requires the tender offeror to pay at least the tender offer price in order to complete a freezeout merger. See Roland Int'l Corp. v. Najjar, 407 A.2d I032, 1037 (Del. I979) (requiring "entire fairness" for freezeout merger); Singer v. Magnavox Co., 380 A.2d 969 (Del. 1977) (requiring business purpose); DeL. CODE ANN. tit. 8, § 262 (r974) (establishing appraisal rights). These restrictions on freezeouts give controlling shareholders incentives to pay minority shareholders a proportional interest in the gains produced by the acquisition.

${ }^{35}$ Fischel, supra note 7; Manne, supra note 23. At least one court has recognized the power of tender offer threats in increasing the price of shares. Dart Indus. v. Conrad, 462 F. Supp. I, 8-9 (S.D. Ind. 1978). 
mium over market value the bidder offered or would have offered but for the resistance or the prospect of resistance. This lost premium reflects a foregone social gain from the superior employment of the firm's assets.

The target's managers, however, have a substantial interest in preserving their company's independence and thus preserving their salaries and status; the less effective they have been as managers, the greater their interest in preventing a takeover. They may disguise a policy of resistance to all offers as a policy of searching for a better offer than any made so far. Extensive manuals describe both the stratagems of resistance and the methods of disguise. ${ }^{36}$ There is no signal that separates intransigent resistance from honest efforts to conduct an auction for the shareholders' benefit. The fact that the first tender offer or any subsequent offer is defeated supplies little information, because any auctioneer understands that determined efforts to collect the highest possible price may lead to no sale at all in the short run. ${ }^{37}$

Even resistance that ultimately elicits a higher bid is socially wasteful. Although the target's shareholders may receive a higher price, these gains are exactly offset by the bidder's payment and thus by a loss to the bidder's shareholders. Shareholders as a group gain nothing; the increase in the price is simply a transfer payment from the bidder's shareholders to the target's shareholders. Indeed, because the process of resistance consumes real resources, shareholders as a whole lose by the amount targets spend in resistance plus the amount bidders and any rivals spend in overcoming resistance. ${ }^{38}$ These additional costs can be substantial. ${ }^{39}$

${ }^{36}$ See authorities collected note 2 supra. See also Lipton, supra note 12 , at I2030. New defensive strategies are constantly being invented. The latest is lobbying for legislation to block the acquisition. See Wall St. J., Feb. I3, I98I, at I9, col. 4 .

${ }^{37}$ Even if the target's management intends to conduct an auction, its noncooperative response to the offer may lead to an inferior disposition of the target's assets. See Polinsky, Controlling Externalities and Protecting Entitlements: Property Right, Liability Rule, and Tax-Subsidy Approaches, 8 J. LEGAL STUD. I (x979) (arguing that noncooperative behavior sometimes frustrates the transfer of resources to the highest valuing users).

${ }^{38}$ As a general matter, expenditures that influence the distribution of trading gains but do not generate better performance are simple waste. Society as a whole would pay to prevent traders from fighting over the gains of trades that are bound to occur anyway. For rigorous demonstrations of this, see Fama \& Laffer, Information and Capital Markets, 44 J. Bus. 289 (197I); Hirshleifer, The Private and Social Value of Information and the Reward to Inventive Activity, 6r AM. ECoN. REv. 56r (I97I). Tender offers at premiums over the market price fall into the class of trades that are bound to occur eventually.

${ }^{39}$ Defensive acquisitions - ones that create antitrust problems for the bidder, but would not otherwise have been made by the target - can be costly to consummate 
This argument may appear to be inconsistent with fiduciary principles. If resistance touches off an auction, it may drive up the price paid for the target's shares. ${ }^{40}$ Ordinarily managers are charged with the duty of maximizing the returns to the firm's shareholders without regard to adverse consequences to other firms' shareholders or to society at large. The standard economic assumption since Adam Smith introduced the invisible hand has been that the firm's rational pursuit of its self-interest yields more gains for it than losses for its rivals. The result is efficient because the winners gain more than enough to compensate the losers.

But this is not invariably true, and the recent experience with pollution provides an example. When a firm treats the air as a free good, society as a whole may lose more than the firm gains. As long as the firm is entitled to disregard the effects on third parties of the pollution it emits, it will consume too much clean air in producing its products.

A related "externality" arises when a target's management resists a tender offer. The resulting increase in the prices paid for target firms will generally discourage prospective bidders for other targets; when the price of anything goes up, the

and may involve inferior uses of the newly acquired assets. Litigation against the offeror, extensive mailings to and solicitation of shareholders, and other defensive tactics can be quite costly to both the target and the bidder. For example, in the recent contest for control of Pullman, the fees paid to lawyers, investment bankers, and similar participants in the fight were $\$ 17$ million. When Mead Corporation defeated Occidental Petroleum's bid in 1979, the cost was \$15 million. See Wall St. J., Dec. 2, I980, at I, col. 6; id. at 23, col. 2. There is a further cost of resistance if the contest prolongs the period before the acquisition can be completed, for that delays the achievement of the gains the acquisition will produce.

${ }^{40}$ Bidding usually serves the function of allocating goods to their highest valued uses; the best indication of the ability to put something to a valuable use is the willingness to pay for it. In the housing market, for example, sellers regularly hire brokers, who conduct an extended "auction" of the house to solicit the highest bid. In the end the owner receives more money, and the house is sold to the person who values it most highly. But a housing auction and a management-run auction for a corporation differ in a number of important respects. Shareholders wishing to auction off their corporation would not employ the firm's managers as their agents in the auction because the managers' interests potentially conflict with the shareholders' interests. See pp. rrg8-99 infra. In addition, the market for corporate shares is far more efficient than the market for parcels of real estate. The former establishes even without an auction the value of corporations as currently managed. There is thus no need to expend resources to duplicate what the market provides for free - an accurate estimate of current value. Given the existence of a market price for shares, we know that the transfer of the target firm to a higher bidding offeror produces gains for both society and the target's shareholders. Even if the first bidder cannot put the target's assets to the best possible use, those assets could be resold and eventually would end up in possession of the firm that valued them most highly. See Coase, The Problem of Social Cost, 3 J.L. \& EcoN. I (I960). Indeed, the first bidder's failure in that situation to resell the target's assets to another higher valuing firm would constitute inferior management that would expose the bidder itself to takeover. 
quantity demanded falls. Changes in the incentives of bidders affect the utility of monitoring by outsiders, and that affects the size of agency costs and in turn the pre-offer price of potential targets' stock. In order to explore the nature of these effects, it would be useful to ask what rational shareholders would do if, before a tender offer was in prospect, they could bind the management to resist or to acquiesce in any offer.

Consider the effects of two polar rules. Under the first rule, management is passive in the face of tender offers. If there are no competing bidders, the first tender offeror will prevail at the lowest premium that will induce the shareholders to surrender their shares. Under the second rule, management uses all available means to resist the offer. This resistance creates an auction, so that no bidder can acquire the target without paying a price almost as high as the shares would be worth under the best practicable management. ${ }^{41}$ For example, shares of firm $X$ are trading for $\$ 40$. Outsiders could manage the firm better so that the shares would be valued at $\$ 90$ each. ${ }^{42} \mathrm{~A}$ bid of $\$ 50$ would induce a substantial majority of $X$ 's shareholders to tender their shares. Under the first paradigm rule - managerial acquiescence - the bid of $\$ 50$ would ensure success. Under the second paradigm - resistance a tender offeror could not acquire $X$ for much less than $\$ 90$ per share.

Which of these rules maximizes the welfare of $X$ 's shareholders? If the question is asked ex post, after a tender offer has been made, then plainly the shareholders would prefer the second rule and the bidding war. But if the shareholders were asked which strategy the managers should pursue ex ante, prior to the offer, they would have substantial reasons to choose acquiescence. It is easy to see why. If the target's shareholders obtain all the gains from the transaction, no one has an incentive to make a tender offer, and thus no one will offer a premium for the shares. ${ }^{43}$ The shareholders will be

${ }^{41}$ Neither rule accurately describes a real possibility. There would always be some competition among offerors no matter what the target's management does, and this competition would ensure that the bidder pays more than the absolute minimum demanded by shareholders. At the same time, no defensive strategy would enable the target's shareholders to receive the last nickel of gain, both because there is substantial uncertainty about the value of the assets in the new owners' hands and because the bidder who can make the best use of the assets would not have to pay much more than the last offer of the bidder who could put the assets to the second highest use. Nonetheless, the paradigm rules reveal tendencies; if one rule is clearly inferior to the other, it follows that other rules similar to the inferior one should be avoided.

42 The shares would be valued at more than $\$ 90$ were there no agency costs.

43 Indeed, there will be inefficiently little investment in monitoring by prospective offerors whenever the target's existing shareholders can capture any of the benefits of 
stuck with their $\$ 40$ shares. Under the strategy of acquiescence, however, the shareholders obtain $\$ 50$ and are better off. 44

Prospective offerors must do substantial research to identify underpriced corporations and to determine how their management can be improved. They may engage investment banking houses and investigate the affairs of many corporations before finding one whose management could be improved. The position of a tender offeror is particularly precarious because, at the time it makes a bid, its investment in information about the target is sunk. Perhaps the first bidder will invest $\$$ Io per share in finding out about many potential targets and then exploring the prospects of $X$ in depth. If it can acquire $X$ for $\$ 50$ per share, it reaps a profit as high as $\$ 30$ per share $(\$ 90$ minus $\$$ Io investigation costs, minus $\$ 50$ tender price). The bidder's profit falls to nothing when the tender offer price reaches $\$ 80$ per share. Once the offeror announces its bid, however, other potential acquirers learn the target's identity. The bid itself, and the accompanying disclosures under federal and state law, may reveal much of what the offeror has learned. ${ }^{45}$ If the offeror does not supply other bidders with valuable information, the target's management may do so as part of a strategy to set up an auction. But any other bidder need not bear costs as high as those already incurred by the first bidder. The subsequent bidders take a free ride, making

the monitor's endeavors. Cf. Grossman \& Hart, supra note 33, at 54-58 (the optimal "dilution factor" for society in takeovers is infinite, meaning that the offeror should be allowed to confiscate the value of untendered shares in order to ensure that all shares will be tendered).

${ }^{44}$ This analysis can be generalized. As we noted at the outset, p. II64 supra, the value of any stock can be understood as the sum of two components: (i) the price that will prevail in the market if there is no successful offer multiplied by the likelihood that there will be none, and (ii) the price that will be paid in a future tender offer multiplied by the likelihood that some offer will succeed. If the shareholders could bind the firm's managers to follow a single rule, they would want them to follow a strategy that maximized $\mathrm{ex}$ ante share value, $(p) \mathrm{T}+(\mathrm{I}-p) \mathrm{M}$, where $p$ is the probability that a tender offer will succeed, $T$ is the tender offer price, and $M$ is the market price of the shares in the event of no takeover. The shareholders would not look solely at $T$, because any rule increasing the size of $T$ decreases $p$ and $M$. Using the numerical example from the text, as $T$ rises toward $\$ 90, p$ falls toward zero, since a prospective offeror would not engage in the costly and risky efforts necessary to investigate prospective targets and make a tender offer if it did not anticipate being able to enjoy a substantial part of the gains.

45 Grossman \& Hart, Disclosure Laws and Takeover Bids, 35 J. FinaNce 323, 327-33 (1980); Grossman \& Hart, supra note 33, at 58 \& n.25; Jarrell \& Bradley, supra note 21 . Indeed, the existence of an offer by itself tells other prospective bidders where to look, even if it conveys no other information. These other bidders can confine their study to the target firm, although the first offeror undoubtedly incurred costs in examining the records and prospects of many firms. 
a profit even if the price rises to $\$ 80$ per share. As a result, no firm wants to be the first bidder unless it has some advantage, such as speed, ${ }^{46}$ over subsequent bidders to compensate for the fact that only it had to incur monitoring costs. And, of course, if there is no first bidder there will be no later bidders and no tender premium.

Perhaps most important of all, requiring bidders to pay a high premium will lead to a decrease in the price of the target's shares. A bidder facing the prospect of paying a high premium is less likely to monitor other firms, and the decrease in searching for targets leads to a decrease in the number of bids. ${ }^{47}$ Then the price of $X$ 's stock is likely to decrease because, with the reduction in monitoring, agency costs rise.

For instance, assume that a bid of $20 \%$ over the market price will attract enough shares under the acquiescence paradigm to achieve success, but under the resistance paradigm the premium must be $50 \%$ or more. As before, firm $X$ 's shares would trade for $\$ 90$ under the best practicable management. The shareholder choosing one of the paradigm rules to bind the managers would ask: How effective will outside monitoring be in inducing my managers to come as close to optimality as possible? The governing rule would influence managers' performance; if takeovers are more costly, there will be fewer diligent managers in any given firm. Agency costs will tend to increase to the point where further increases precipitate a takeover.

Under a rule of acquiescence, where a premium of $20 \%$ carries the day, excess agency costs cannot for long exceed \$I5 per share. If the price falls below $\$ 75$ per share $(\$ 90$ divided by 1.2 ), then potential bidders will begin to see the prospect of a profitable takeover. The farther the price falls below $\$ 75$, the more profitable and hence the more likely a takeover. Things look quite different to the shareholder, though, under the resistance paradigm. Then the price could fall to $\$ 60$ ( $\$ 90$ divided by $\mathrm{r} .5$ ) in the market without attracting any interest from potential bidders. The more effective resistance is in raising the premiums after tender offers are made, the lower

46 If the making of a bid itself triggers an auction, the initial bidder is at a disadvantage unless the period for tendering is very short. Before the enactment of the Williams Act and state tender offer statutes, offers typically were open for only a few days. See pp. 1162-63 supra. Speed was the essence of success. The statutes creating delays have made auctions more effective in increasing tender premiums, but in the process they have decreased the number of successful tender offers. Jarrell \& Bradley, supra note 2I, at 398-403; see Fischel, supra note 7. Managerial tactics that intensify the bidding war simply aggravate the problem a prospective offeror faces in determining whether to invest in monitoring.

47 The available data show that the number of offers decreases as resistance increases. See Jarrell \& Bradley, supra note 21 , at $398-403$. 
the share price can fall without attracting interest by bidders. ${ }^{48}$ The shareholder trying to choose a set of instructions to management consequently would conclude that his welfare is best served by instructions to acquiesce. Such instructions give managers the greatest incentive to perform optimally. ${ }^{49}$

2. The Acquiescence Paradigm as an Implicit Shareholder Agreement. - Our argument implies that resistance is costly to shareholders and that logically they should seek to avoid those costs by instructing managers to acquiesce in tender offers. Theoretically, shareholders could assure acquiescence by insisting on appropriate provisions in the articles of incorporation or bylaws. Such provisions would facilitate monitoring of managerial performance, and consequently the price of shares of corporations with antiresistance provisions should rise relative to other firms. Moreover, corporations must compete in the capital markets for funds, and they could obtain these funds at lower cost if their articles constrained the defensive maneuvers of management.

Yet articles of incorporation rarely if ever contain antiresistance provisions. To the contrary, they sometimes contain provisions to make acquisition difficult. Classified boards, cumulative voting, supermajority consent rules, and similar provisions may frustrate the tender offeror's attempts to take control after it has purchased a majority of the common stock. ${ }^{50}$ These provisions raise the effective price of an ac-

48 Of course, the shareholder would not think that resistance versus acquiescence is the sole determinant of agency costs. Many other things, including monitoring within management teams, influence the size of these costs. See p. II72 supra. But to the extent that a rule about resistance to tender offers affects these costs, the direction of the influence is plain.

49 We have constructed the analysis in this subsection on the basis of a number of simplifying and highly unrealistic assumptions. We have assumed that managers are not attempting to defeat all offers and in their efforts to conduct an auction never misjudge the price bidders would pay and so never erroneously defeat the offers. We have assumed that managers never attempt to use resistance to appropriate to themselves some portion of the additional premium available in an auction. If these assumptions are relaxed, then the shareholder's choice of which instructions to issue to management becomes even easier. When managers have a right to resist, they can sell nonresistance for soft jobs, comfortable consulting contracts, and substantial severance bonuses. E.g., Singer v. Magnavox Co., 380 A.2d 969 (Del. 1977) (resistance dropped after management obtained employment contracts). It would be very difficult for a court to separate these disguised bribes from the many economically desirable employment and consulting arrangements worked out in mergers. The shareholder could prevent that misappropriation of his gains - and the accompanying transactions costs borne by the target - by issuing binding instructions to acquiesce in tender offers.

so M. Lipton \& E. Steinberger, supra note 2, §6.2 (1978 \& Supp. 1980), provides a catalogue of structural provisions designed to make takeovers difficult and costly. See also Hochman \& Folger, supra note 2. 
quisition and increase the offeror's risk. Managers sometimes recommend to shareholders that such provisions be added to the articles of incorporation, and shareholders routinely follow these recommendations.

But these facts hardly suggest that shareholders approve of management resistance. The great majority of public corporations have not adopted "porcupine" provisions making acquisitions more difficult, and general principles of fiduciary duty restrict managers' options to do so. ${ }^{51}$ More important, shareholders would find it impossible to instruct managers to acquiesce in tender offers because of the very agency and monitoring problems that lead to the offers. Individual shareholders do not have the incentive to attempt to insert antiresistance provisions into the bylaws or articles of incorporation or to oppose management on suggested porcupine provisions, because no shareholder or coalition of shareholders can capture the full value of such an action to the shareholders as a group. If such a provision were inserted, managers could probably delete it again by amendment. ${ }^{52}$ Even if one shareholder waged a campaign on behalf of shareholders' interests, few others would pay any attention, because no one shareholder's vote is likely to affect the outcome. Dissatisfied shareholders are more likely to sell their stock than attempt to change the corporation's bylaws or otherwise oppose management. ${ }^{53}$

The situation here is similar to the situation in many other areas of corporate law that recognize shareholders' inability to monitor managers' performance. The Trust Indenture Act, ${ }^{54}$ Bankruptcy Code ${ }^{55}$ state corporation codes, and other statutes

\footnotetext{
Si Numerous courts have recognized that managers' attempts to perpetuate themselves in control breach their fiduciary duty. See, e.g., Lerman v. Diagnostic Data, Inc., $42 \mathrm{I} \mathrm{A.2d} 906$ (Del. Ch. I980) (holding that managers may not change proxy election rules if the change entrenches them in office); Cheff v. Mathes, $4 \mathrm{I} \mathrm{Del}$. $\mathrm{Ch}$. 494, I99 A.2d 548 (I964); Auerbach v. Bennett, 47 N.Y.2d 6I9, 393 N.E.2d 994, 4I9 N.Y.S.2d 920 (1979). Supporters of defensive action against tender offers repeatedly counsel managers not to be candid about their objectives, lest candor lead to a finding of violation of fiduciary responsibilities. E.g., M. LIPTON \& E. STEINBERGER, supra note 2, § 6.1.I (1978 \& Supp. 1980) ("Preparation of a 'black book' of procedures to be used in the event of a takeover attempt is not desirable because it may be used to embarrass management in litigation by creating a 'credibility gap' for a management that states it has acted in good faith and carefully considered a raider's offer."); Lipton, supra note 12, at 120-30 (elaborate script for camouflaging the target's reasons for resisting an offer).

52 Grossman \& Hart, supra note 33 , does not take proper account of this problem in arguing that the founders of a corporation will select rules that make takeovers attractive.

s3 See pp. II 70-7I supra.

${ }^{54}$ 15 U.S.C. $\$ \S 77 a a a-77 b b b b$ (1976 \& Supp. III I979).

5S II U.S.C. \$§ IOI-766, I1OI-II46 (Supp. III r979).
} 
provide standard form "contracts" of the sort shareholders would be likely to choose if they were in a position to do so. With respect to tender offers, as elsewhere, the instructions to managers must be imposed from outside the corporation. ${ }^{56}$

\section{The Arguments Supporting the Right of Target Management to Adopt a Defensive Strategy}

Our analysis cuts against the grain of many cases and a substantial amount of commentary. The rationales offered to support the right of target management to resist tender offers can be grouped in four categories: (I) tender offers do not increase welfare; (2) the target's shareholders benefit from price increases when tender offers are defeated; (3) the target's management has obligations to noninvestor groups that may be adversely affected by a tender offer; and (4) the target's management is obligated to prevent unlawful conduct. In the sections that follow, we consider and reject each of these rationales as a basis for resistance. ${ }^{57}$

\section{A. The Arguments That Tender Offers Do Not Increase Welfare}

Our argument relies on the premise that tender offers increase social welfare by moving productive assets to highervalued uses and to the hands of better managers. Numerous commentators, however, have reached a contrary conclusion. It has been observed, for instance, that many target companies are "well run," have substantial amounts of cash from successful operations, and that the offeror retains the target's management after acquiring control..$^{58}$ These observations are invoked to support an assertion that the acquired firms were not doing poorly; consequently, the argument concludes, tender offers do not move assets to better managers.

This is unpersuasive. It amounts to second-guessing the market. Unless the acquirer is giving away its money, the premium price paid for the shares indicates a real gain in the productivity of the assets. If General Motors is willing to bid $\$$ roo for a ton of steel owned by General Electric, and GE

56 This is not, however, a general argument for governmental control of the provisions of corporate charters. Far from it. Once the market for corporate control and the market for shares are operating efficiently, corporate managers will be led to choose whatever provisions of internal government maximize shareholders' wealth: See R. WINTER, supra note 26.

57 We do not consider again the argument that defensive tactics are beneficial because they raise the offer price, viewed ex post. See pp. II75-80 \& notes 38-49 supra.

${ }^{58}$ See, e.g., Lipton, supra note 12. 
sells, we would count this as a value-increasing transaction despite the fact that GE otherwise would have put the steel to "good use" (perhaps $\$ 90$ worth). The highly subjective observation that acquired firms are well run does not exclude the possibility that, in new hands, the firms would be better run. Only proof that markets are not efficient in pricing shares could support the argument that tender offers do not improve the use of resources.

That acquired firms often are cash rich, perhaps implying successful past operations, also does not demonstrate that takeovers are undesirable. To the contrary, that a firm holds a substantial cash position indicates agency costs. Cash can be invested. The acquirer usually invests the cash it obtains in the takeover, thus putting idle resources to work. The retention of the target's management after a takeover also is not significant. Although the management may keep their old titles, they often lose effective control to officers of the acquirer: Retention in office may be a form of bribe, paid to secure acquiescence in the takeover, rather than a signal of satisfactory performance. ${ }^{59}$

Martin Lipton has advanced a related argument: Tender offers decrease social welfare because they "adversely affect long-term planning and thereby jeopardize the economy." 60 But he fails to demonstrate how long-term planning is "adversely affected," let alone the economy jeopardized. The threat of takeovers does not prevent managers from engaging

59 Retention also would be expected under the specific information approach taken by Jarrell \& Bradley, supra note $2 \mathrm{I}$.

${ }^{60}$ Lipton, supra note 12 , at 105. Lipton states that the issue is "[w]hether the long-term interest of the nation's corporate system and economy should be jeopardized in order to benefit speculators interested not in the vitality and continued existence of the business enterprise in which they have bought shares, but only in a quick profit on the sale of those shares." Id. at ro4. As discussed in the text, Lipton is simply wrong in concluding that tender offers injure the long-term interests of the corporate system and economy. Moreover, his attack on speculators (arbitrageurs) who are interested "only in a quick profit on the sale of [their] shares," id., is unwarranted. Arbitrageurs perform a constructive role by purchasing and selling shares. They offer shareholders who wish to sell their shares at a profit in advance of a tender offer (and thereby avoid the risk that the offer will be defeated, oversubscribed, or never made) the opportunity to do so. By constantly searching for firms that are likely to be the subject of a tender offer, arbitrageurs also make the market more efficient. Finally, arbitrageurs, by selling their shares to an offeror, contribute to the transfer of assets to those who can manage them more efficiently. That the arbitrageurs are not interested in "the vitality and continued existence of the corporate enterprise in which they have bought shares," $i d$., hardly distinguishes them from the typical shareholder of the large publicly held corporation. Arbitrageurs, like other shareholders, buy and sell shares in order to make a profit. By doing so, they contribute to market efficiency, provide a necessary check on suboptimal management, and facilitate the transfer of control to more capable managers. 
in long-range planning. If the market perceives that management has developed a successful long-term strategy, this will be reflected in higher share prices that discourage takeovers. To be sure, the risk of a tender offer ensures that corporate managers will be unable to assume that they can continue in office indefinitely. But this risk of displacement does not reduce welfare. Precisely the opposite is true; some insecurity of tenure is necessary to spur managers to their best performance. Society benefits from an active takeover market, therefore, because it simultaneously provides an incentive to all corporate managers to operate efficiently and a mechanism for displacing inefficient managers.

Harold Williams, former Chairman of the Securities and Exchange Commission, has argued that tender offers decrease welfare because they divert resources that otherwise could be used for capital investments and instead are used only to rearrange the ownership of existing corporate assets. ${ }^{61}$ The answer to this argument is that funds used to finance a tender offer are not necessarily diverted from investment to consumption. They are merely shifted from the acquiring corporation to the target's shareholders. The acquiring corporation could equally well have distributed these funds as dividends or put them to other non-investment uses. There is also no reason to assume that the target's shareholders will use these funds for consumption rather than capital investment. The shareholders may reinvest what they receive from the tender offeror. There is, therefore, no reason to conclude a priori that an active takeover market diverts funds from capital investment. ${ }^{62}$

Tender offers have also been characterized as "raids" in which the offeror pays a premium for a working majority of the shares in order to loot the firm to the detriment of the minority shareholders. ${ }^{63}$ It is unlikely, however, that any

${ }^{61}$ Speech by Harold Williams Before the Seventh Annual Securities Regulation Institute (Jan. 17, r980), reprinted in [1979-1980 Transfer Binder] FED. SEc. L. REP. (CCH) I 82,445. The Director of Policy Planning of the Federal Trade Commission has made a similar argument. Reich, Pie-Slicers vs. Pie-Enlargers, WASH. MONTHLY, Sept. I980, at I3.

62 Williams' argument is based on the premise that we should encourage firms with accumulated cash to make new capital outlays in plant and research and development, rather than encouraging these firms to take over other existing firms. This argument, however, would deny shareholders the right to the most profitable rate of return by forcing firms to make new capital outlays when a takeover or merger would be more profitable. Williams' related concern that the tender offer dollars paid to target shareholders may not be invested because of the dearth of new equity issues in recent years would be best answered by tax measures to encourage new equity, such as lowering the $70 \%$ maximum individual income tax on dividends.

${ }^{63}$ This argument was raised most frequently during debates on the Williams Act and is still frequently made on behalf of the target's managers. Its classic expression 
tender offer for a substantial percentage of a company's shares will be motivated by a desire to loot the acquired corporation. A looter generates no new value, and thus cannot afford to pay a premium price for all shares. Even if a bidder seeks less than all shares, it cannot pay a significant premium for those it obtains. If, for example, the offeror acquires for $\$$ I5 per share $70 \%$ of a firm whose shares had been trading for \$Io, it cannot hope to make a profit by looting. Also, looting from minority shareholders violates established rules, ${ }^{64}$ and a bidder would not be likely to escape detection if it violated these rules.

Another argument against tender offers portrays them as reducing the welfare of the shareholders of the acquirers by more than the premium paid to the target's shareholders. In this view, tender offers represent self-aggrandizing empire building by acquiring managers who err in deciding what firms to acquire or what price to pay. ${ }^{65}$ The difficulty with this view is its implicit assumption that product and labor market constraints (and the tender offer process itself) do not discipline managers. A corporation headed by an empire-building management team that did not maximize profits would fare poorly in the product market and would have lower share prices; its managers would fare poorly in the employment market. The corporation itself would become a takeover candidate.

Finally, it has been suggested that takeovers create monopolies. ${ }^{66}$ Profit increases that come about because of monop-

is the statement by Senator Harrison Williams in commenting on an earlier version of the Williams Act:

In recent years we have seen proud old companies reduced to corporate shells after white-collar pirates have seized control with funds from sources which are unknown in many cases, then sold or traded away the best assets, later to split up most of the loot among themselves ... .

The ultimate responsibility for preventing this kind of industrial sabotage lies with the management and the shareholders of the corporation that is so threatened. But the leniency of our laws places management and shareholders at a distinct disadvantage in coming to grips with the enemy.

III CONG. REC. 28257-58 (I965).

Looting may be seen as similar to stealing, which redistributes rather than increases welfare. However, if looting were prevalent, a decrease in welfare would actually occur, as the risk of looting perpetrated by managers with no interest in running acquired companies well was factored into the price of shares ex ante. This would lead to a reduction in all share prices.

${ }^{64}$ See, e.g., Gerdes v. Reynolds, 28 N.Y.S.2d 622 (Sup. Ct. 194I).

${ }_{65}$ Marris \& Mueller, The Corporation, Competition, and the Invisible Hand, 18 J. ECON. LITERATURE 32, 36-37, 42, 46 (I980) (discussing other articles).

${ }^{66}$ See, e.g., I Mergers and Economic Concentration: Hearings on S. 600 Before the Subcommittee on Antitrust, Monopoly and Business Rights of the Senate Judiciary Committee, 96th Cong., Ist Sess. 61-106 (I979) (testimony of Assistant Attorney General John Shenefield) [hereinafter cited as Merger Hearings]. But see G. BENSTON, CONGLOMERATE MERGERS 26-3i (I980). 
olization produce reductions in social welfare. This view, however, is contradicted by the evidence. Most tender offers raise no antitrust problems, and one careful study has shown that takeovers generally reduce concentration in the acquired firms' markets. ${ }^{67}$

The raider, managerialist, and monopolist models of tender offers are also contradicted by data on stock price movements. Most of the movement in the price of a stock is correlated with movement in the market as a whole and depends on general economic conditions. But the movements in individual stock prices net of movements in the market give a rough picture of the fortunes of the issuing companies, and data about these movements for individual companies - called cumulative average residuals, or CAR's - are powerful indicators of a company's performance.

Each of the views of tender offers, including the welfaremaximizing view that we advance, implies a particular pattern of acquirers' and targets' CAR's. The proposition that tender offers move assets to better uses implies that, because the acquirers are looking for targets with suboptimal performance, the prices of the targets' shares would decline relative to the market for a period prior to the offer. The targets' CAR's would begin to rise again, shortly before the offer was announced, as information leaked to the market. The CAR's of the untendered shares would show significant gains over the preannouncement position. The offeror's CAR's should show little abnormal movement, because offerors should not be able to make more than a competitive return (given the extent of risk) on their investment in the target.

If, on the other hand, tender offers are conducted to raid the assets of the targets, the CAR's of targets would be steady until word of the offer leaked to the market; then they would decrease, as investors feared the worst. The CAR's of the minority, untendered shares would plummet after the acquisitions were completed. The CAR's of offerors should rise, in anticipation of gains from looting, once word reached the market.

If tender offers harm the acquirers because their management acquires the wrong firms or pays prices that are too high, then the acquirers' CAR's should be steady or declining until word leaks, after which they would decrease. The CAR's of the targets would be steady until shortly before the offer, when

${ }^{67}$ Goldberg, The Effect of Conglomerate Mergers on Competition, I6 J.L. \& ECON. I37 (1973). See also R. Posner \& F. EASterbrook, ANTItrust $921-42$ (2d ed. rg8I). 
they would increase. Untendered shares would not appreciate in price.

Finally, if tender offers are an instrument of monopolization, the CAR's of both firms should be steady before word of the acquisition spreads, and then both CAR's should rise in anticipation of monopoly profits. ${ }^{68}$

A great deal of evidence has been accumulated on the movement of CAR's before and after tender offers. ${ }^{69}$ The evidence shows that the CAR's of acquired firms decline steadily for approximately forty months before the offer. A month or two before the offer, they begin to rise. After the offer has been completed, the nontendered shares continue to trade at a significant increase over the pre-offer price. The CAR's of the offerors rise when the offer is made. The estimates of gains to targets' shareholders run from $14 \%$ to $50 \%$; the estimated gains to offerors' shareholders are $5 \%$ to $10 \% .{ }^{70}$

${ }^{68}$ The CAR's we have described for the various views of tender offers will not necessarily describe the status of every target firm but rather will describe averages. For instance, the raid theory does not require that pre-offer market-line residuals of every target be steady. An occasional pre-offer decreasing or increasing residual is compatible with the raid theory. However, because average residuals are zero (indicating that share prices track market price movements), we would expect on average flat CAR's for targets under the raid theory. This is because the raid theory suggests no reason why acquirers would be looking for firms whose performance is not average.

${ }^{69}$ Bradley, Interfirm Tender Offers and the Market for Corporate Control, $53 \mathrm{~J}$. Bus. 345 (I980); Dodd, Merger Proposals, Management Discretion, and Stockholder Wealth, 8 J. FINANCLAL EcoN. I05 (1980); Dodd \& Ruback, Tender Offers and Shareholder Returns, 5 J. Financial EcON. 35I (I977); Ellert, Mergers, Antitrust Law Enforcement and Stockholder Returns, 3I J. FINANCE 7I5 (I976); Jarrell \& Bradley, supra note 21; Kummer \& Hoffmeister, Valuation Consequences of Cash Tender Offers, 33 J. FINANCE 505 (1978); Mandelker, Risk and Return: The Case of Merging Firms, I J. FINANCIAL ECON. 303 (I974). Other studies are summarized in R. POSNer \& K. SCOTt, Economics of Corporation LAw and Securities RegULATION 228-3I (1980); G. BENSTON, supra note 66, at 35-45; 2 Merger Hearings, supra note 66, at 9-48 (testimony of Richard Posner).

70 Dodd \& Ruback, supra note 69 , found that targets' shareholders received average premiums of $21 \%$ and acquirers' shareholders obtained nominal gains. Bradley, supra note 69 , at 346 , concluded that the targets' shareholders received a premium of $49 \%$ (relative to the price two months before the offer), while bidders' shareholders obtained an appreciation of $9 \%$ over the same period. Dodd, supra note 69 , found gains of $33.96 \%$ to targets' shareholders relative to the price Io days before the offer. Mandelker, supra note 69 , at 314 , found gains of $14 \%$ for the targets' shares and no abnormal gains for offerors. Jarrell \& Bradley, supra note $2 \mathrm{r}$, at 389-90, found premiums of $30 \%$ to $70 \%$ for the targets' shareholders.

These results obviously differ on the extent of the gains. But differences such as this should be expected. The studies concentrate on different samples of offers in -different years, and they use different periods of reference for computing price changes. It should not be surprising, therefore, that some studies also appear to find that takeovers produce little effect. Firth, The Profitability of Takeovers and Mergers, 89 ECoN. J. 3r6, 323 (1979), concluded that in the United Kingdom from 1972 to 1974 offerors suffered losses that almost exactly offset the gains of the targets' shareholders. 
In the judgment of the market, then, tender offers increase welfare. They rescue firms with declining CAR's but do not hurt the acquiring firms. Most of the gain goes to shareholders of the target, who benefit whether or not they tender. After the acquisition has been completed, the minority untendered shares of the target continue to trade at prices significantly higher than the pre-offer price. ${ }^{71}$ The acquiring firms' prices increase continuously before the acquisition - not the pattern we would expect if bidders were managed by self-aggrandizing men. ${ }^{72}$ This pattern of security prices is inconsistent with the raiding, managerialist, and monopolist views of tender offers but is consistent with the value-maximizing approach that we adopt. $^{73}$

\section{B. The Argument That Share Price Increases Justify Resistance from Target's Management}

Several commentators have noted that even if a tender bid fails, the share price of the target often rises, sometimes to more than the tender offer price. ${ }^{74}$ If shareholders so benefit, the argument goes, then management is justified in resisting tender offers. Although the data marshalled to support this

Firth speculated that the market structure of the United Kingdom might be different in some respect from that of the United States but otherwise was at a loss to explain his findings. Other scholars conclude that bidders suffer slight losses. Dodd, supra note 69 , found that successful bidders appear to sustain losses of $7.22 \%$. Marris \& Mueller, supra note 65 , at 42,46 , summarizes other studies indicating that bidders may be slightly optimistic. But this, too, is consistent with our approach; if an auction occurs, the prize goes to the highest bidder, and the highest bid is the most likely to suffer from unfulfillable expectations.

71 Although the nontendering shareholders receive substantial gains, Bradley, supra note 69 , at 346 , finds that they do not receive quite as much as the tendering shareholders. This tends to confirm the argument of Grossman \& Hart, supra note 33 , at 46 , that corporations will allow acquirers to "dilute" the nontendered shares slightly in order to encourage a majority of shareholders to tender.

72 Both Mandelker, supra note 69, and Ellert, supra note 69, found that the CAR's of acquiring firms increased substantially in the four to eight years before the offer. This suggests that offerors are doing relatively well and that the offer serves to bring new assets within the control of the offerors' superior managers.

${ }^{73}$ Most of those who argue that tender offers do not increase welfare neglect the wealth of recent data. For example, Gelfond \& Sebastian, supra note 12, at 45358 , asserts that tender offers do not move assets to higher valued uses yet cites none of the recent relevant studies of CAR movements. And Lipton, supra note 12, at 10609, ignores not only these studies but the earlier profit studies as well. It was in the beginning of the I970's that economists developed the procedures necessary to discriminate among the possible explanations for tender offers. Any analysis that overlooks these results is of dubious validity.

${ }^{74}$ Dodd \& Ruback, supra note 69, at 362-63; Jarrell \& Bradley, supra note 21, at 397-98; Lipton, supra note 12 , at 106-09, 132-33. 
point varies in quality, ${ }^{75}$ the premiums offered in unsuccessful offers appear to be less than the appreciation after the offer is defeated. ${ }^{76}$ This fact calls for explanation.

The most plausible reason for a price increase following the tender offer's defeat is that the market sees the defeat as simply one round in an extended auction. The market anticipates that in the future another offeror - one not saddled with the first offeror's higher costs of information - will acquire the target. Many management-induced withdrawals are followed by higher offers, ${ }^{77}$ and share prices increase as the eventual acquisition becomes more likely. ${ }^{78}$

Another possible explanation for the price increase following a defeated tender offer is that the offer itself served to rouse the target's management to action. The offer warned management to improve its performance, and either the offer or the accompanying public disclosure may have provided the target's management with the information to do so. ${ }^{79}$

Regardless of the cause of the price increase, shareholders in general have little cause for rejoicing. The price rise comes about because someone is taking a free ride on information generated by the first offeror. Free riding of this sort reduces the incentive to make the first offer, and, for the reasons we have developed earlier, decreases the amount of monitoring,

75 In particular, Lipton's data is unpersuasive. See Lipton, supra note 12 , at I06-09, I32-33. Lipton studied 36 unsolicited tender offers that were defeated between 1973 and 1979 . Nineteen of the 36 target firms were trading at a higher price than the rejected offer as of June 1979. But Lipton does not attempt to determine whether the price changes resulted from general market movements or from the defeat of the tender offer. Nor does he consider the possibility that the price of the firm's shares would have been still higher if the tender offer had succeeded. Finally, by focusing on share price after an offer is defeated, Lipton ignores the ex ante interest of shareholders in keeping prices high. See pp. II $77-80$ \& notes $4 \mathrm{I}-49$ supra.

${ }^{76}$ See Bradley, supra note 19 , at $348,368-72$. Bradley found that unsuccessful offers had a premium of $29 \%$, while the shares appreciated $45 \%$ relative to their price two months before the offer. He concluded that this finding demonstrates that shareholders have rational expectations - that is, that they refuse to take an offer if the shares will become more valuable on the defeat of the offer. Id. at 375 .

77 See Lipton, supra note 12 , at 106-08.

78 The data discussed in note 70 supra appear to support the explanation. However, to test our hypothesis precisely would require dividing targets into two classes - those in which managers demonstrate a plan to defeat all offers, and those in which managers attempt to elicit a higher offer. We predict that the price of the former will plummet when the tender offer is withdrawn, while the price of the latter will rise relative to the pre-offer price. No such research has been done, perhaps because of the considerable difficulty of separating firms accurately into these two categories.

${ }^{79}$ See Dodd \& Ruback, supra note 69; Grossman \& Hart, Disclosure Laws and Takeover Bids, supra note 45; Jarrell \& Bradley, supra note 2 I. 
decreases the number of offers, and harms shareholders in the long run. ${ }^{80}$

\section{The Argument That Directors Have a Duty to Protect the Interests of Noninvestor Groups}

Several commentators have argued that directors of a target company, when confronted with a tender offer, have a duty to consider the interests of various noninvestor groups such as employees, customers, creditors, and the community in general. ${ }^{81}$ Even if a tender offer presents shareholders with an opportunity to sell at a profit, these commentators would allow management to resist the tender offer if it believed that the offer would adversely affect these noninvestor groups.

This proposal is deeply flawed. First, its advocates make no attempt to explain why a successful tender offer should be deleterious to the corporation's employees, suppliers, or creditors. Takeovers improve economic efficiency, and that improvement usually enhances the position of those who deal with the firm. The new owners cannot improve the firm's performance by discarding valuable employees or suppliers or by harming the interests of creditors. ${ }^{82}$ The new owner would harm itself in the process of harming the firm. Second, even if the new owners have new policies concerning employees, plant location, and so on, how can existing managers know whether these policies are detrimental on balance? Most likely the existing managers have little information about the operational decisions to be made by their successors. And if they had such information, what could they do with it? ${ }^{83}$ Which

so See p. rr75 supra (defensive strategies are not beneficial even though they raise the offer price).

${ }^{81}$ Lipton, supra note I2; Steinbrink, supra note I2; Speech of Harold Williams Before the Seventh Annual Securities Regulation Institute, supra note 6r.

82 If maintaining good community relations is in the interest of the firm, then the new owners will maintain the existing policies. And if the target's community relations were not in the firm's interests, then the old management was diverting shareholders' wealth to friends or other favorites. If the existence of such diversion were demonstrable, it would amount to a breach of the managers' fiduciary duty to shareholders whether or not a takeover occurred.

${ }^{83}$ Managers should not be allowed to consider whether creditors, suppliers, or employees will be displaced in deciding whether to oppose a tender offer. The risk of displacement is an inevitable and indispensable characteristic in any free market economy. Any attempt by management to minimize this risk by preventing new owners from having the opportunity to operate more efficiently, with existing or (if necessary) new inputs of productior, is anticompetitive. Such behavior is more characteristic of medieval guilds than of free markets.

Moreover, as we have emphasized, outsiders have no incentive to discard existing policies that are in the firm's best interests. Cf. McKenzie, Frustrating Business Mobility, REG., May/June $\mathrm{r} 980$, at 32 (arguing that proposed laws that attempt to 
groups are to be considered by management? Should management be obligated to balance losses to existing noninvestor groups against the (presumably greater) gains to other noninvestor groups as a result of the tender offer? ${ }^{84}$ Even if these hurdles can be overcome, how should management balance the effect of a tender offer on noninvestor groups with the impact on shareholders? ${ }^{85}$

Finally, the proposed approach amounts to rejection of the idea that agents (managers) are accountable to their principals (shareholders). So long as it continues to be lawful to form corporations for profit, shareholders are entitled to hire managers dedicated to the shareholders' interests alone. The duty of management is to operate efficiently and thus maximize the return to shareholders. ${ }^{86}$ Maximization of shareholders' wealth ultimately works to the advantage of workers and suppliers, because shareholders gain only from the firm's mutually beneficial transactions with those persons. If the proposed approach were adopted, however, management would, in certain

minimize employee and community dislocation by preventing businesses from moving to areas where they can operate more efficiently are anticompetitive and hurt the communities and workers they attempt to protect).

84 The argument has been made that defense is justified because the target firms are run by "locals," with appropriate concern for their home towns, and that the new "outside" owners will disregard these ties. Cf. Herald Co. v. Seawell, 472 F.2d ro8I (roth Cir. 1972) (directors of newspaper have obligation to public and employees in addition to stockholders). This argument is overly provincial. Why should the old suppliers or the community in which the firm operates count for more than the new suppliers or new home base chosen by new management?

85 If a successful tender offer would give shareholders a $20 \%$ return on their investment, but might cost certain employees their jobs, should management oppose the tender offer? What if the premium is larger but a longtime creditor might lose a valuable source of business? The number of problems could be multiplied indefinitely. Our point is that although management, at least in nonconflict-of-interest situations, is best situated to determine what actions will maximize the return to shareholders, it is hardly qualified or authorized to balance shareholders' interests against the uncertain effects of an acquisition on various vaguely defined noninvestor groups.

${ }^{86}$ This is unquestionably the prevailing view. See Dodge v. Ford Motor Co., 204 Mich. 459, 507, 170 N.W. 668, 684 (rgrg) ("A business corporation is organized and carried on primarily for the profit of the stockholders. The powers of the directors are to be employed for that end. The discretion of directors is to be exercised in the choice of means to attain that end and does not extend to a change in the end itself ...."); Corporate Director's Guidebook, 33 Bus. LAw. 1595, I62 I (1978); Hetherington, Facts and Legal Theory: Shareholders, Managers and Corporate Responsibility, 2I StAN. L. REV. 248, 279-80 (I969). The most recent cases continue to adhere to this view. One court, for example, held that United States Steel Corporation had no common law or contractual obligation to consider the effects of plant closures on employees or the communities in which the plants were located. Local r330, United Steel Workers v. United States Steel Corp., 631 F.2d 1264, 1279-82 (6th Cir. 1980). But of. Herald Co. v. Seawell, 472 F.2d I08I (Ioth Cir. 1972) (holding that directors of newspapers have obligation to public and employees in addition to stockholders). 
cases, sacrifice the interest of the shareholders to the interests of noninvestor groups. ${ }^{87}$ Such a result, far more than the separation of ownership and control or any other characteristic of the modern corporation, would greatly prejudice shareholders by decreasing the incentive of management to act in their best interest. A manager responsible to two conflicting interests is in fact answerable to neither. A principle of divided loyalty ultimately would harm everyone by reducing the willingness of people to entrust their money to managers. ${ }^{88}$

\section{The Argument That Directors Have a Duty to Prevent Violations of Law}

A final justification for resistance to tender offers is target management's alleged duty to prevent unlawful conduct. ${ }^{89}$ In furtherance of this duty, managers have instituted litigation against offerors to prevent asserted violations by the offerors of the antitrust laws and the Williams Act. In many cases, the expense and delay caused by the litigation are sufficient to defeat the tender offer, even if the underlying claim is frivolous.

But what is the source of management's duty? If managers act on behalf of shareholders, the duty must come from a need to prevent injury to these shareholders. If a given act involves a violation of law, penalties may follow. Managers' duty calls for them to minimize the sum of penalty costs and the cost of compliance with the rule. ${ }^{90}$ But the first link in the chain is the possibility of injury. There is no duty to spend the firm's resources to prevent some other party from exposing itself to a penalty. Indeed, unless a party is actually injured by a violation, it generally does not have even the right to sue. The question, therefore, is what injury (in penalties or other costs) the target corporation or its shareholders could suffer if the offeror violates the law.

With respect to alleged antitrust violations, it is difficult to see how the shareholders will suffer "loss or damage by a

${ }^{87}$ Jensen \& Meckling, Rights and Production Functions: An Application to Labor-managed Firms and Codetermination, 52 J. Bus. 469 (1979), makes a convincing argument that programs in which noninvestors have claims to the firm's income will make all claimants (including the nonowners) worse off.

88 This defect in the proposal for management responsibility to noninvestor groups is shared by similar proposals to place representatives of various constituent groups on the board of directors. Apart from the insoluble practical problems of determining who should be on the board and how votes should be allocated, constituent representation plans inevitably have the effect of decreasing management's accountability to shareholders.

${ }^{89}$ See, e.g., Lipton, supra note I2; Steinbrink, supra note 12.

90 See Engel, An Approach to Corporate Social Responsibility, 32 Stan. L. Rev. r, 37-58 (r979). 
violation of the antitrust laws."91 The acquired company suffers no "loss or damage" because it generally becomes richer rather than poorer. ${ }^{92}$ Only the acquirer can violate the Clayton Act; 93 the target's shareholders are not exposed to any risk of penalty.

Shareholders who receive and hold the offeror's stock could conceivably be injured, however, if the new combined firm is assessed treble damages for an antitrust violation. But this possible future injury would not serve as the justification for an antitrust suit brought by the target's management. There is no assurance that such damages will be assessed. The shareholders could avoid any risks by selling in the market. That the bidder's stock is worth more than the target's shares surrendered in the offer suggests strongly that the possible future liability is less than the apparent future gains from the offer. Because the target's management has a duty to the tendering shareholders who risk losing the tender offer premium if the offer is defeated, it cannot logically raise the uncertain prospect of antitrust liability as a reason why shareholders should be compelled to forego a sure gain. Management's proper course if it believes that a successful tender offer would violate the antitrust laws is to refer the matter to the Department of Justice. ${ }^{94}$

Suits to redress alleged violations of section $I_{3}(d)$ of the Williams Act ${ }^{95}$ present a more difficult problem. Because Congress has enacted the statute to ensure that shareholders of a target company receive accurate information concerning the offeror and its plans, ${ }^{96}$ the offeror's noncompliance may injure the target's shareholders. It is by no means clear, however,

91 To obtain injunctive relief under $\S 16$ of the Clayton Act, I5 U.S.C. $\S 26$ (I976), a party must establish "loss or damage by a violation of the antitrust laws." See Brunswick Corp. v. Pueblo Bowl-O-Mat, Inc., 429 U.S. 477 (I977). The Court held there that a plaintiff cannot recover damages unless it can demonstrate antitrust injury; that is, it must prove that its injury resulted from that which made the defendant's conduct unlawful. After Brunswick a strong argument can be made that a target company has not suffered any antitrust injury resulting from the tender offer, even if an illegal combination results. See Fischel, supra note 7, at 38. This same point has been made more recently in 2 P. AREEDA \& D. TURNER, ANTITRUST LAw If $346 \mathrm{~b}$, at $248-49$ (1978), and was apparently adopted in A.D.M. Corp. v. Sigma Instruments, Inc., 628 F.2d 753, 754 (Ist Cir. I980).

${ }^{92}$ See Missouri Portland Cement Co. v. Cargill, Inc., 498 F.2d 85I, 866-67 (2d Cir.), cert. denied, 4 I9 U.S. 883 (I974).

${ }_{93}$ Section 7 applies only to acquiring firms. 15 U.S.C. $\&$ I8 (I976).

94 Management also could inform the shareholders of its belief and let them make their own decision whether to tender.

${ }^{95} 15$ U.S.C. $\$ 78 \mathrm{~m}(\mathrm{~d})(\mathrm{r})$ ( 1976$)$.

96 For critical analyses of this requirement that an offeror disclose its plans, see Fischel, supra note 7, at 12-13; Grossman \& Hart, Disclosure Laws and Takeover Bids, supra note 45; Jarrell \& Bradley, supra note 21. 
that management should be allowed to represent shareholders' interests under the Williams Act by bringing suit; the interests of the two groups may conflict in this situation, ${ }^{97}$ and there is too great a risk that a management-initiated suit will be a dilatory tactic intended to defeat a tender offer beneficial to shareholders. ${ }^{98}$ Here, as with antitrust concerns, management's best course is to refer the matter to the appropriate government agency, in this case the Securities and Exchange Commission.

\section{The Business Judgment Rule and MANAGERIAL PASSIVITY}

Our thesis that managers of target companies should acquiesce when confronted with a tender offer has not been adopted by courts and state legislatures. As we indicated at the outset, courts have generally gone in the opposite direction, holding that directors have not only the right but also the duty to resist tender offers that they believe to be not in the best interests of their shareholders. ${ }^{99}$ Although some decisions find particular defensive tactics to be unlawful, ${ }^{100}$ they are exceptions to the general rule permitting or even requiring defensive strategies.

The most significant conceptual impediment to judicial, and perhaps even legislative, adoption of a rule requiring managerial passivity has been the notion that assessing the economic merits of tender offers, like judging the merits of any other prospect facing the corporation, is peculiarly within the ability of management. This sense that decisions regarding the future of the corporation are best made by its managers is embodied in the business judgment rule ${ }^{101}$ - a common law

${ }^{97}$ For a discussion of the conflict of interest between managers and shareholders when a tender offer has been made, see pp. II97-98 infra.

${ }^{98}$ Another barrier to a suit to enjoin a tender offer for a violation of $\S \mathrm{r} 3(\mathrm{~d})$, is U.S.C. $\$ 78 \mathrm{~m}(\mathrm{~d})(\mathrm{r})$ (1976), by the offeror is that the Williams Act contains no such express private right of action. Compare Dan River, Inc. v. Unitex Ltd., 624 F.2d I 2 16 (4th Cir. 1980 ) (holding that a target may sue under $\S$ I3(d)), and Kirsch Co. v. Bliss Laughlin Indus., [x980 Transfer Binder] FED. SEC. L. REP. (CCH) $\uparrow 97,580$ (W.D. Mich. July I, I980) (same), with Gateway Indus. v. Agency Rent A Car, Inc., [rg8o Binder] FED. SEC. L. REP. (CCH) I 97,540 (N.D. Ill. June Io, 1980) (no private right of action under $\S \mathrm{I} 3(\mathrm{~d})$ ).

${ }^{99}$ See p. 1163 supra.

100 Klaus v. Hi-Shear Corp., 528 F.2d 225 (9th Cir. 1975); Podesta v. Calumet Indus., [1978 Transfer Binder] FED. SEC. L. REP. (CCH) I 96,433-34 (N.D. Ill.); Condec Corp. v. Lunkenheimer Co., 230 A.2d 769 (Del. Ch. 1967).

${ }^{101}$ See p. II63 supra. The precise meaning of the rule is in dispute. Compare Veasey \& Manning, Codified Standard - Safe Harbor or Uncharted Reef, 35 Bus. 
doctrine that, at least outside the realm of tender offers, has long insulated managerial decisions from judicial scrutiny. Under the business judgment rule, managers enjoy considerable freedom to direct the corporation as they see fit. Without some showing of either bad faith or self-dealing, courts almost uniformly refuse to subject the decisions of managers to review on the merits.

Our purpose in this Part is to harmonize our proposal of managerial passivity with the business judgment rule and demonstrate that the rule should never serve to justify a decision to oppose a tender offer. We also attempt to provide some guidelines for courts to use in determining whether management has engaged in conduct for the purpose of defeating a tender offer.

\section{A. The Rationale and Limits of the Business Judgment Rule}

The shareholder-owners (and also bondholders) of a corporation must select agents (managers) to run its affairs. If the corporation is publicly held, the managers are unlikely to own a significant proportion of the firm's securities. As we have repeatedly emphasized, agency costs are an inevitable consequence of this relationship. Yet courts generally do not scrutinize managers' conduct. Quite the contrary, after satisfying themselves that particular business decisions were made in good faith by the managers and were not tainted by selfdealing, courts invoking the business judgment rule typically decline to inquire further. While it may at first appear anom-

LAw. 9I9 (1980), with Arsht \& Hinsey, Codified Standard - Same Harbor But Charted Channel: A Response, 35 Bus. LAw. ix (July I980).

The recent case of Treadway Cos. v. Care Corp., 638 F.2d 357 (2d Cir. 1980), rev'g in part 490 F. Supp. 668 (S.D.N.Y. I980), illustrates the strength of the business judgment rule, once it has been invoked. Care acquired $3 \mathrm{r} \%$ of Treadway's stock and indicated an intent to obtain control. Treadway's management responded by "selling" a large block of shares to a third party; the buyer obtained a commitment by Treadway to repurchase the shares. The district court concluded that this deal was inexplicable except as a strategem to frustrate Care and to maintain Treadway's managers in office, and it found that Treadway had made no serious study of the consequences of a takeover by Care. It enjoined Treadway from voting these new shares. The court of appeals reversed, relying on the business judgment rule. It found that the plaintiffs had not carried their initial burden of establishing that the directors had an interest in the transaction or acted in bad faith. Id. at 380-88. It therefore was irrelevant that the directors could not establish that they had a proper purpose in issuing the shares.

Treadway is not a tender offer case - it involved an attempted takeover through a proxy contest by a minority shareholder. Such a situation raises some prospect that the new controlling party will not look after the interests of the majority of the shareholders. The case is, therefore, not strictly inconsistent with the analysis of the business judgment rule that we offer below. It is, nonetheless, at odds with the spirit of our proposal. 
alous for courts to give managers such broad discretion given the inevitability of agency costs, there is no tension between the rule and shareholders' welfare.

The application of the business judgment rule contributes to the efficient management that shareholders desire. There is no reason to think that courts generally could improve the performance of managers. Courts lack the experience and information necessary to make business decisions. Although sometimes a court might be able to detect inferior decisionmaking or other agency costs, the burden of inquiry in the run of cases almost certainly would carry costs larger than the gains available in the few cases where courts could improve matters. Even if judges were well suited to the task of reviewing business judgments, the ratio of suits to improvements would be high, because plaintiff-shareholders, just like courts, would lack the information necessary to challenge managerial decisions intelligently.

Moreover, it is doubtful that shareholders would gain from having better decisions made on the basis of additional information developed in litigation. Many business decisions are made on the basis of suggestive but inconclusive information. Rational shareholders would not have it otherwise, however, for their welfare is maximized by decisions that yield the highest profits net of the costs of gathering information and making the decisions. Yet after things go awry, it is easy for a shareholder to contend that managers gathered too little information. If information-gathering and deciding costs are disregarded - as they often are by courts - then a different business decision may be preferred over the one management actually took. But because shareholders would not want managers to disregard information-gathering and deciding costs in search of better decisions, they also would not favor a legal rule that paid too little attention to those costs.

There is no reason to believe that judicial scrutiny is more effective in policing management than various market forces, which provide incentives to management to operate efficiently and keep share prices high. One mechanism creating such an incentive is the market for corporate control, particularly the tender offer market, which we have discussed at length. Indeed, the ability of shareholders freely to trade their shares, and thereby vote on current management, is no doubt the most powerful check on agency costs. ${ }^{102}$ Other market incentives exist to ensure that management will generally act in the best interests of shareholders. Competition in the product and 
services market, for example, ensures that a firm that is inefficiently managed will not survive over time. Similarly, the market for managerial services provides managers with considerable incentive to operate efficiently so as to increase the market value of their own services. ${ }^{103}$ Finally, various compensation packages, such as stock option plans, by making managers owners, also attempt to provide management with incentives to keep share prices high by linking managerial compensation to the firm's performance. ${ }^{104}$ In light of these various incentives to keep share prices high, management's interest in maximizing share price corresponds (if imperfectly) to the shareholders' interest in maximum return on their investment. There is little need to add to these automatic devices a process of judicial review that is costly and unlikely to identify or correct real errors of business judgment.

But market forces are not fully effective in making the interests of managers and shareholders coincide. Some selfdealing transactions pose an especially great risk of malfeasance. The clearest example of this may be emptying the corporate treasury and fleeing to Honduras with the proceeds. At the same time, courts are especially adept at discovering fraud, deceit, or pocket-lining in business transactions. An inquiry into fraud does not require an examination of the wisdom of any business decision.

For these reasons, the rules that govern the managers' duty of care have been distinguished from the rules governing the duty of loyalty. When managers have acute conflicts of interest, they must bear the burden, unaided by any presumption or deference, of establishing that the transaction was "fair" (beneficial) to the firm. ${ }^{105}$ The duty of loyalty and the duty of care thus are treated differently, with the business judgment rule covering only the latter. This limitation on the scope of the business judgment rule, like the basis of the rule itself, rests on principles that maximize the welfare of shareholders.

103 Poor management may lead to reductions in the managers' salaries and bonuses. Other managers may also fire the shirkers. Fama, supra note 28; Jensen \& Meckling, supra note 24 . Managers with a history of poor performance will also command lower salaries at other firms.

${ }^{104}$ Stock option plans, however, cannot eliminate the problem of suboptimal management. See note 3I, supra.

${ }^{105}$ E.g., Lewis v. S.L. \& E., Inc., 629 F.2d 764 (2d Cir. I980); Wilderman v. Wilderman, 315 A.2d 610 (Del. Ch. 1978); Ross Transport, Inc. v. Crothers, I85 Md. 573, 45 A.2d 267 (1946). See also Maldonado v. Flynn, 4r3 A.2d $125 \mathrm{I}$ (Del. Ch.) (refusing to apply the business judgment rule to a motion to dismiss a derivative suit), contingently dismissed on res judicata grounds, 417 A.2d 378 (Del. Ch. 1980) (in light of Maldonado v. Flynn, 483 F. Supp. 274 (S.D.N.Y. I980)). 


\section{B. Defensive Tactics and the Business Judgment Rule}

In view of the recognized limits on the scope of the business judgment rule, it is surprising that courts have invoked the rule so freely as a basis for refusing to review the defensive conduct of managers faced with a hostile tender offer. A frequent consequence of a successful takeover attempt is the replacement of incumbent managers. For acquirers, replacement of target management is typically a significant motive for making the tender offer in the first place; for the target's shareholders, such offers present the most effective means of manifesting disapproval of management. Given the serious and unavoidable conflict of interest that inheres in any decision on one's own ouster, courts ought not to make available to a manager resisting a tender offer - and, in effect, fighting against his own replacement - the same deference accorded to the decisions of a manager in good standing.

Indeed, unlike transactions involving a conflict of managerial interest outside the realm of tender offers, efforts undertaken by target management primarily to resist a takeover bid should not even be susceptible of the justification that they happen to benefit the target. Such efforts to resist should instead be proscribed completely. Conflicts transactions outside the realm of tender offers are not similarly interdicted because they typically involve corporate decisions that shareholders, as a practical matter, simply cannot make. ${ }^{106}$ But in deciding whether to accept or reject a tender offer, managers enjoy no particular comparative advantage over shareholders. The decision does not involve management of the corporation's affairs in any meaningful sense and thus can be made by shareholders even though they are not involved in those affairs to any significant degree.

Moreover, the rationales underlying the policy of judicial restraint embodied in the business judgment rule in no way counsel against implementation of a rule of managerial passivity. The deference accorded managerial decisions under the

\footnotetext{
106 The decision whether to oppose a tender offer is different from other "interested" director transactions such as the setting of salaries or the making of contracts with a related entity. Because of the dangers presented by a conflict of interest in these latter situations, courts are likely to scrutinze these transactions closely to prevent harmful self-dealing. But it could not seriously be argued that the best way to minimize the risks created by a conflict of interest would be for shareholders to establish the salaries of directors or make contracts for the corporation. These types of decisions, regardless of the inevitable conflict of interest, must be made by management as agents for the firm; the shareholders themselves have neither the time, the expertise, nor the interest to become involved with running the corporation's affairs.
} 
business judgment rule reflects, in part, the inability of courts to make better business decisions than managers and, in part, the inefficiency that would result were managers encouraged to disregard the costs of gathering information and making decisions. A rule of managerial passivity does not require courts to make business decisions at all, let alone better decisions than managers. To implement a rule of passivity, all a court need do is determine whether managers were passive. ${ }^{107}$ It need not gather costly information nor induce managers to incur inefficiently large costs of decisionmaking to stave off litigation. Under a rule of passivity, managerial decisions would be subject to attack only if designed to defeat takeover bids, and not for being inadequately researched. ${ }^{108}$

\section{The Role of Management in Responding to a Tender Offer Compared with the Role of Management in Other Fundamental Corporate Changes}

Our proposal that managers should be passive in response to a tender offer might appear to be at odds with the broad

${ }^{107}$ See pp. I20I-03 infra.

${ }^{108}$ Some commentators have suggested, however, that if the decision to oppose a tender offer is taken pursuant to the recommendations of a truly independent committee of the board of directors, courts should apply the business judgment rule. Gelfond \& Sebastian, supra note 12; see Speech by Harold Williams Before the Seventh Annual Securities Regulation Institute, supra note 6r. This proposal fails to take account of several considerations. "Independent" directors may not be so independent in passing on such matters, for they effectively serve at the pleasure of the managers whose jobs are at stake in a takeover. These managers provide the information on which the outside directors will act. See Galef v. Alexander, 6I5 F.2d 5I (2d Cir. I980); Maldonado v. Flynn, 4I3 A.2d x25I (Del. Ch.), contingently dismissed on res judicata grounds, $4 \mathrm{r} 7 \mathrm{A.2d} 378$ (Del. Ch. I980) (in light of Maldonado v. Flynn, 483 F. Supp. 274 (S.D.N.Y. I980)). But $c f$. Lewis v. Anderson, 6r5 F.2d 778 (gth Cir. I980) (good faith exercise of business judgment by special litigation committee is immune from judicial scrutiny); Auerbach v. Bennett, 47 N.Y.2d 6I9, 393 N.E.2d 994, 4I9 N.Y.S.2d 920 (1979) (no judicial inquiry into actions of special litigation committee appointed by board of directors). More important, however, the independent director proposal assumes that directors, even if disinterested, have the right to decide for the shareholders, ex post, whether or not the shareholders may sell their shares. By making this assumption, however, the independent director proposal disregards the need for a binding policy of acquiescence in order to maximize shareholders' welfare ex ante. Any attempt to resist a tender offer will have the effect of increasing the amount of agency costs by raising the offerors' costs and decreasing the number of offers. And the resulting decrease in the effectiveness of monitoring will lead to a fall in the price of shares when the assessment is made ex ante. This decline in share price will occur regardless of whether the managers (or disinterested directors) decide to resist. See pp. II 75-80 supra. For shareholder wealth to be maximized ex ante, the decision whether or not to sell when a tender offer is made must be made by the shareholders and by shareholders alone. 
discretion that management has in negotiating a merger or deciding whether the firm should be sold or liquidated. ${ }^{109}$ The difference in treatment is justified, however, by the differences between the role played by the board in tender offers and its role in these other situations.

By statute, ${ }^{110}$ the board of directors negotiates a merger as the firm's agent. So long as the board continues to exercise agency authority, there is little reason to second-guess its decision to disapprove a merger. Only at great cost, if at all, could a court determine whether rejection of a proposed merger was a mistake. The performance of the board in its role as agent is policed by market forces. If the board attempts to siphon the benefits of the merger to itself, or obstinately refuses to negotiate based on a policy of being independent, the prospective partner can simply make a tender offer. The tender offer, therefore, is an essential safety valve to ensure that managers evaluate merger proposals in the best interests of the shareholders. ${ }^{111}$ A legal rule that allowed the target's management the same discretion in responding to a tender offer as it has in responding to a merger proposal, therefore, would decrease the number of mergers as well as the number of tender offers, because a valuable check on management would be lost.

The analogy to the lack of any obligation on the part of management to make a periodic decision whether to sell or liquidate is similarly irrelevant. A tender offer presents shareholders with a concrete price at a premium over market. The offeror has borne the necessary costs of investigation, and the target's shareholders obtain the benefit. In contrast, the board could not decide whether to sell or liquidate without investing substantial sums in getting an estimate of realizable proceeds. The advice of investment bankers or other experts is inexact and quite expensive. Constant expenditure of funds for this purpose is not likely to be justified.

If it could somehow be determined that the firm is worth more sold or liquidated than as a going concern, then it should

${ }^{109}$ Several commentators have suggested that the rules concerning tender offers be modeled on the role of the board in mergers. E.g., Lipton, supra note I2; Herzel, Schmidt \& Davis, supra note 12 . It has also been suggested that since directors have no obligation to make a periodic decision whether to sell or liquidate, they should similarly have no obligation to accept a tender offer. Lipton, supra note 12.

110 State corporation statutes typically provide that a vote of the directors is necessary to submit a merger proposal to the shareholders. See, e.g., Del. CodE ANN. tit. 8, \& 25I(b) (r974).

111 This safety valve aspect of tender offers is implicitly recognized by state corporation statutes, which typically require that directors approve a merger proposal but impose no similar approval requirement in the case of tender offers. 
be sold or liquidated. This is a fundamental principle of bankruptcy law.112 True, management of a solvent firm has no duty to sell or liquidate in this situation. But if it does not, the company will be an attractive tender offer candidate. The offeror then can sell or liquidate and thereby appropriate the resulting gains for itself and for remaining minority shareholders. Again, therefore, the tender offer acts as a safety valve and helps to induce managers to serve the shareholders' interests.

\section{The Meaning of Managerial Passivity}

Although we have concluded that shareholders would want management to be passive in the face of a tender offer, we have not attempted to define precisely what we mean by passivity. Doubtless, managers must carry out the corporation's ordinary business. Perhaps, too, management should be able to issue a press release urging shareholders to accept or reject the offer. ${ }^{113}$ The offeror also will convey its views to the shareholders, who can act on these messages in light of the self-interest of both the management and the offeror. ${ }^{114}$ But almost any other defensive actions expend the target's resources and produce no gain to investors. Thus, management should not propose antitakeover charter or bylaw amendments, file suits against the offeror, acquire a competitor of the offeror in order to create an antitrust obstacle to the tender offer, buy or sell shares in order to make the offer more costly, give away to some potential "white knight" valuable corporate information that might call forth a competing bid, or initiate any other defensive tactic to defeat a tender offer. ${ }^{115}$

Our proposal for managerial passivity does not mean, however, that managers must go to sleep when they suspect an

112 N. Buchanan, The Economics of CoRPoRate ENTERPRISE chs. I $_{4}-\mathrm{r}_{5}$ (1940).

${ }_{113}$ SEC Rule $x_{42}$-2, 17 C.F.R. 240.14e-2 (1980), requires the target's management to inform the shareholders of its position with respect to a tender offer within Io days of its announcement. This release of information may lead to a change in share prices, and defeat of the offer, if significant facts previously were unknown to traders.

See p. I168 supra.

${ }^{114}$ Section I4(e) of the Williams Act prohibits false and deceptive statements by both a target and an offeror. I5 U.S.C. $\$ 78 \mathrm{n}(\mathrm{e})$ ( $(976)$.

${ }^{115}$ It is irrelevant to our analysis whether the incumbent management has a "policy" dispute with the offeror. We question, therefore, the approach in the line of Delaware cases which hold that directors can lawfully expend resources to defend their positions when corporate policy is at stake. E.g., Cheff v. Mathes, 4I Del. Ch. 494, I99 A.2d 548 (I964); Kois v. Carey, 39 Del. Ch. 47, r58 A.2d I36 (rg60); Martin v. American Potash \& Chem. Corp., 33 Del. Ch. 232, 92 A.2d 295 (I952); see Fischel, supra note 7 , at $35,40-42$. 
imminent tender offer. A requirement of managerial somnolence would deprive the corporation of valuable business opportunities and might give firms a device for hindering their competitors' operations. Yet many legitimate business decisions could have the effect of making the corporation less attractive to the bidder and thus could be called resistance. It is also possible, however, that many business decisions, ostensibly taken for the purpose of seizing valuable business opportunities, are actually undertaken for the purpose of defeating the tender offer. Distinguishing resistance from passivity will be simple in some cases and hard in others.

Management will frequently leave clues, however, that suggest its motive. The recent decision in Panter $v$. Marshall Field $\&$ Co. ${ }^{116}$ illustrates this process. Marshall Field operates a number of high quality department and specialty stores. Although frequently the subject of overtures to merger, Field has rejected each one. ${ }^{117}$ Field also made a number of acquisitions in the past, apparently for the purpose of creating antitrust problems for potential bidders. ${ }^{118}$ Field resisted again when Carter Hawley Hale, another retailer, prepared to make a cash tender offer. Field filed suit urging that the acquisition would violate the securities or antitrust laws; it urged its shareholders not to tender, arguing that the price was too low; it made several defensive acquisitions that not only aggravated a potential antitrust problem but also made Field less attractive as Carter's merger partner; ${ }^{119}$ Field's board authorized the management to take "such action as they deemed necessary" in order to defeat the offer altogether. ${ }^{120}$

Under our view that managers should be passive in response to a tender offer, Marshall Field is an easy case. Management's departure from passivity was unmistakeable and constituted a clear breach of fiduciary duty. ${ }^{121}$ But how would the case have proceeded if Field had issued a public statement of neutrality while proceeding with the acquisition? A prophylactic rule that would prevent management from making profitable acquisitions would harm shareholders, yet applica-

${ }^{116} 486$ F. Supp. 1 r68 (N.D. Ill. 1980), appeal docketed, No. 80-r375 (7th Cir. Mar. 21, I980).

${ }^{117}$ Id., slip op. at 1177 .

118 Id.

119 Id. at $1177-84,1188-90$.

${ }^{120} I d$. at $1180-84$.

121 The district court, however, held that the directors of Marshall Field did not violate any fiduciary duty. Id. at Ir94-95. This holding was based on the premise, erroneous in our view, that the business judgment rule provides management with the right, and even the duty, to resist a tender offer that it deems to be not in the best interests of the firm or its shareholders. 
tion of the usual business judgment rule would give managers free rein to carry out disguised programs of resistance.

The timing of managerial action provides a useful, if imperfect, basis for resolving this dilemma. On the one hand, courts could simply presume, subject to rebuttal by a litigant who established the contrary, that any plans or programs set in motion before target managers had reason to believe that there would be a takeover attempt were not undertaken with a view to resisting the tender offer. ${ }^{122}$ Such plans would presumptively comply with the rule of passivity and would thus enjoy the freedom from judicial scrutiny otherwise available under the business judgment rule. ${ }^{123}$ On the other hand, if actions that materially hindered either the offer or the acquisition were taken immediately after management first had reason to know of an impending offer, then courts could presume that the actions were undertaken with a view to defeating the offer. ${ }^{124}$ The target's managers could be allowed to overcome the presumption, but only by a substantial demonstration that their actions were undertaken for the economic benefit of the target rather than for the purpose of defeating the offer.

122 The business judgment rule should not apply, however, to unambiguous preventive defense tactics such as shark-repellant charter and bylaw amendments. This type of resistance (which, we have emphasized, is a form of suboptimal management) should be prohibited per se.

123 The principal problem with any such approach is that it creates an incentive for managers to take their defensive steps in advance - to build moats and barricades. They could, for example, insert in the bylaws of the firm provisions that make takeover costly; a bonus of $\$ 20$ million to be paid to any person involuntarily transferred from one job to another, or a mandatory dividend of $\$ 20$ per share whenever one person gains more than $25 \%$ of the shares would be possible (if farfetched) provisions. These second-best responses could in principle be as effective as existing defensive strategies in preventing takeovers, yet we know (from the fact that they are not now employed) that they are more costly to the target than today's antitakeover devices. Our proposal is hardly desirable if it simply drives managers to construct new methods of resistance or new ways of disguising old methods. We conclude, nonetheless, that problems of second-best solutions are not a sufficient objection to the analysis presented here. Similar objections could be raised to most other legal rules. The rule against price-fixing cartels, for example, might induce firms to substitute territorial or customer allocations that are costly to design, enforce, and disguise. Yet society has sufficient confidence in the benefits of the rule against price fixing that the risk of such undetectable devices seems worth running. The same is true with tender offers.

${ }^{124} \mathrm{See}$ cases cited note 4 supra. In some cases, however, management will resist a tender offer in order to prevent the offer from interfering with plans set in motion before the takeover attempt. See Crouse-Hinds Co. v. InterNorth, Inc., 634 F.2d 690 (2d Cir. rg8o). Resistance in this situation is inconsistent with our proposal of managerial passivity and should be prohibited. 
This allocation of burdens places on the management which has a clear conflict of interest and superior access to information about the reasons for and consequences of its deeds - the responsibility of justification. It meets two essential criteria: it does not incapacitate management from seizing profitable business opportunities just because another firm is attempting to acquire the target, and it also does not freely allow defensive strategems. We do not doubt that the standard would prove troublesome in some cases, but it would resolve most cases, such as Marshall Field, quickly and inexpensively. 